\title{
On the other side of the ditch: exploring contrasting ecosystem service coproduction between smallholder and commercial agriculture
}

\author{
$\underline{R e b e c k a ~ H e n r i k s s o n ~ M a l i n g a ~}^{1,2}$, Graham P. W. Jewitt $^{2,3}$, Regina Lindborg $^{4}$, Erik Andersson $^{1}$ and Line J. Gordon $^{1}$
}

\begin{abstract}
Managing for increased multifunctionality of agricultural landscapes is a crucial step toward a sustainable global agriculture. We studied two contrasting agricultural landscapes that exist in parallel on two sides of a ditch in the South African Drakensberg Mountains. The large-scale commercial and smallholder farmers operate within a similar biophysical context but have different farming intensities, management practices, socioeconomic positions, ethnic identities, cultural contexts, and land tenure systems. To assess multifunctionality, we examined the ecosystem services coproduced within these two social-ecological systems, by applying a mixed-method approach combining in-depth interviews, participatory mapping, and expert assessments. The results indicate clear differences between the two farming systems and farmer groups in terms of supply, demand, and the capacity of the farmers to influence ecosystem service production within their landscapes. Commercial farmers can generally produce agricultural products to meet their demand and have the capacity to mitigate land degradation and erosion. Smallholder food production is low, and the demand for ecosystem services is high. Since the smallholders lack the resources to mitigate unsustainable use, this leads to overuse and land degradation. Both landscape types manifest aspects of multifunctionality but vary in the outcomes. Unequal access to land; skills; and natural, financial, and technical resources can hamper multifunctionality and the development toward an equitable and sustainable agriculture in South Africa.
\end{abstract}

Key Words: agricultural landscapes; inequity; multifunctionality; participatory mapping; poverty traps

\section{INTRODUCTION}

A 56-year-old grandmother of 12 is the head of a family in a homestead consisting of 6 small houses, most of which are built of homemade bricks and thatched roofs. Three of her 6 children have settled within the homestead. The family owns 8 cattle and 4 goats that graze in the communal grasslands during summer months, and they grow maize and beans on their 2 small fields that add up to 2 ha. The grandmother, a smallholder farmer, is the main worker on the fields but gets assistance from the other family members when they are available. Right next to one of her fields runs a $2 \mathrm{~km}$ long ditch, which marks the boundary of the neighboring, commercial farm. From the ditch up to the farmyard stretches 150 ha of maize fields surrounding the house of the farmer, a 38-year-old father of 3 children who are practicing farming by taking care of the family's 260 sheep and 740 cows. This farmer inherited a 1200 ha farm from his father and extended it by buying an additional 500 ha of grazing land a few kilometers away. These 2 neighbors are examples of the 2 starkly contrasting farmer groups, smallholder and large-scale commercial farmers, who operate in the agriculture-dominated mountain foothills of the South African Drakensberg (Fig. 1). These 2 farmers also represent 2 distinctly different land tenure systems: communal village under traditional tenure rules and privately owned land with exclusive access. This is an inequitable system with its origins in the 17th century, intensified during the apartheid era and which still tenaciously persists. It is reasonable to assume that these two farmers aim to produce from their land to their best capacity to sustain their families. The biophysical context of the two farms is fairly similar, the natural vegetation being dominated by grasslands, the soils are similar, and the overall hydroclimate is the same. However, the agricultural landscapes that they manage are rich in contrasts. We explore these contrasts and what it means in terms of differences in ecosystem service coproduction.

Ecosystem services, being the benefits humans obtain from interacting with nature, relate to many dimensions of human wellbeing (Ernstson 2013, Reyers et al. 2013). These interactions, between the natural environment, human skills and decisions, technology and infrastructure, and socio-cultural organization and institutions, result in the coproduction of ecosystem services (Lele et al. 2013, Duraiappah et al. 2014, Huntsinger and Oviedo 2014). Agricultural landscapes, and the people embedded in these, can provide a wide range of ecosystem services, including food, recreation, cultural heritage, aesthetic appreciation, biodiversity, and erosion regulation, and are home to a variety of people and cultures (Bindraban and Rabbinge 2012, DeClerck et al. 2016). A multifunctional landscape is a social-ecological system that sustains the delivery of food, fuel, and fiber to a society while promoting other ecosystem services, and that simultaneously meets the multiple needs, i.e., environmental, social, and economic, of diverse sets of beneficiaries within society (Reyers et al. 2012, Hodbod et al. 2016). Managing for increased multifunctionality is a crucial step toward a long-term sustainable global agriculture (DeClerck et al. 2016, Rockström et al. 2017). However, policies to promote management of agricultural landscapes to achieve integrated environmental, social, and economic goals require novel ways of measuring and rewarding the performance of agricultural systems beyond food production and profit (Sal and García 2007, Hodbod et al. 2016, Holt et al. 2016). Thus, analysis of multifunctionality must not only consider the various factors that underpin the coproduction of the services,

\footnotetext{
${ }^{1}$ Stockholm Resilience Centre, Stockholm University, Sweden, ${ }^{2}$ Centre for Water Resources Research, University of KwaZulu-Natal, South Africa, ${ }^{3}$ Umgeni Water Chair of Water Resources Management, School of Engineering, University of KwaZulu-Natal, South Africa, ${ }^{4}$ Department of Physical Geography, Stockholm University, Sweden
} 
Fig. 1. Illustrations of the study area in the Drakensberg mountain range in South Africa. (a) The landholdings and land uses (cropland and grazing land) belonging to the 10 large-scale commercial farmers and the 2 smallholder villages. (No other land uses are displayed to avoid identification of individual farm locations and to assure confidentiality of the respondents.) (b and c) Smallholder and commercial croplands divided by the ditch portrayed in the introduction. Photos taken by R. Malinga (2009). (d) A satellite image of the ditch separating 1 smallholder village and 1 commercial farm, from Google Earth (2009).
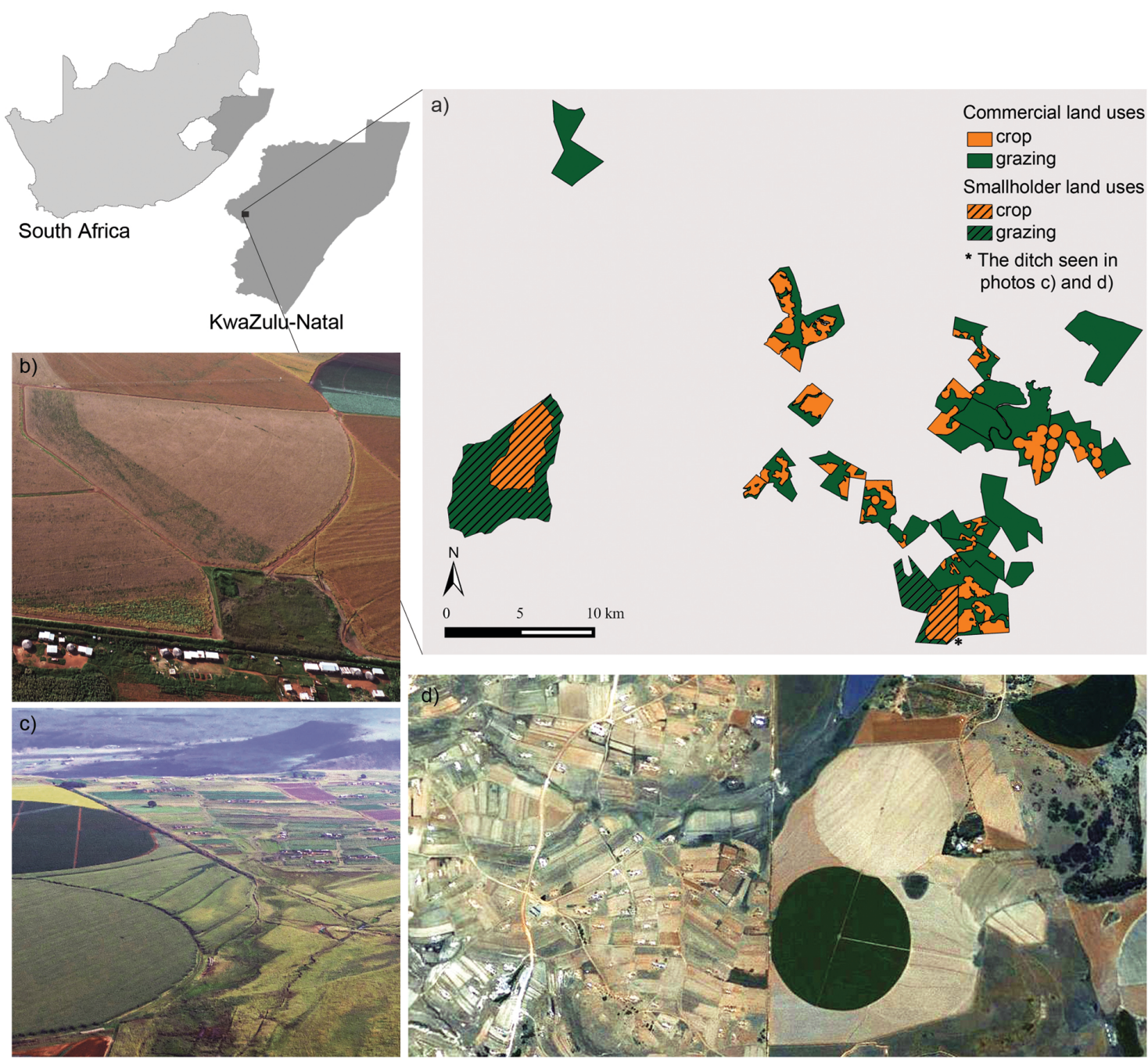

but also assess the diversity of demands for, values attached to, and benefits associated with ecosystem services by different groups of beneficiaries (Bennett et al. 2015, Pascual et al. 2017).

Besides the biophysical prerequisites of the land, the potential of agriculture to provide multiple ecosystem services to society is influenced by management practices, which in turn are influenced by the socioeconomic contexts of the people who live and operate within the agricultural landscapes. At the level of governance, the delivery of ecosystem services is arbitrated by the suite of institutions in place, such as land tenure, communal rules and norms, and taxes and subsidies (Duraiappah et al. 2014). To our knowledge, no study exists that systematically compares ecosystem service outcomes from agricultural systems that have more or less the same biophysical conditions and are managed for similar products, but with substantially different socioeconomic contexts, including the complexity of different and inequitable land tenure systems. Some publications present comparative analyses of environmental outcomes from smallholder and large-scale commercial agriculture, but they generally focus on single features, e.g. productivity (Lele and Agarwal 1990), soil degradation (Essiet 1990), environmental impact (Lee et al. 2014), biodiversity (Andersson and Lindborg 2014), or climate change adaptation (Wilk et al. 2013). Other studies compare high- and low-intensive or organic and conventional agriculture in terms of biodiversity conservation and ecosystem services (Björklund et al. 1999, Haas et al. 2001, Kleijn et al. 2009, Kremen and Miles 2012), but these studies lack apparent contrasts in farm sizes and have long distances between the different farming landscapes (Andersson et al. 2015). 
Our objectives are, first, to explore the coproduction of multiple ecosystem services by assessing the supply of and demand for services in contrasting agricultural landscapes and, second, to discuss the relevance for policies that promote multifunctionality with consideration of diverse values, uses, management, and land access among different groups of beneficiaries.

We focus on a unique setting where two types of farming, i.e., smallholder and large-scale commercial (hereby commercial), are situated side by side, in many instances only separated by a ditch or a fence. The biophysical conditions are the same, and both systems have livestock and maize cultivation as the dominant production system. We apply an explorative mixed-method approach to both map, at the farm level, the supply of and demand for multiple ecosystem services in these highly contrasting agricultural systems and assess the capacity of the farmers to influence the coproduction of ecosystem services in their landscapes. We further discuss to what degree the different landscapes could be considered multifunctional and what constrains the potential to increase their multifunctionality.

\section{STUDY AREA}

The study area is located in the foothills of the Drakensberg mountain range, in the upper part of the Thukela River catchment, South Africa (Fig. 1). The mean annual precipitation ranges from about $550 \mathrm{~mm} / \mathrm{yr}$ in the lower valley regions, to 2000 $\mathrm{mm} / \mathrm{yr}$ in parts of the Drakensberg Mountains, with an altitude of $3000 \mathrm{~m}$ above sea level (Lynch 2004). The region has 2 small towns, Bergville and Winterton, although the majority of the population is rural. The land is mainly used for commercial privately owned agriculture with large crop fields and grazing areas or communal smallholder agriculture presenting a mosaic of small crop fields and communal grazing land. Smallholder farmers and commercial farmers operate with different farming intensities, management practices, socioeconomic positions, ethnic identities, cultural contexts, and land tenure systems.

\section{The farms}

Our analysis is based on 20 farms, represented by 10 commercial farmers (male) and 10 smallholder farmers ( 5 female and 5 male). Twelve of the farmers participated in a previous study within the same project (Malinga et al. 2013), where contact and trust between the researchers and the farmers were already in place. These farmers were asked to identify an additional 8 farmers to participate in the study.

The smallholder farmers represent 2 different village communities: 5 from Potshini and 5 from Okhombe, which are approximately $30 \mathrm{~km}$ apart. The altitudes range from 1165 to 1610 $\mathrm{m}$ and 1250 to $2030 \mathrm{~m}$ above sea level in Potshini and Okhombe, respectively. The 2 villages share the characteristics of typical Zulu farming communities in the Drakensberg. The land in such communities is managed under traditional authority, meaning that community leaders distribute land to families to be used for homesteads and small crop fields, rarely more than a few hectares. Once assigned to a family or individual, this land becomes clearly defined for exclusive use and inheritance within the family (Cousins 2009). The villages are surrounded by communal grazing land, managed by community leaders and used collectively by livestock owners within the community.
The crop fields are small (about 1 ha), typically low yielding and rain fed, and vegetable gardens are watered by small-scale rainwater harvesting solutions (Kongo and Jewitt 2006, Sturdy et al. 2008, Mansour et al. 2013, Salomon et al. 2013, Smith et al. 2014). Maize is the main crop, followed by bean varieties, with all the cultivation taking place in summer and harvest in autumn. Some smallholder farmers rotate and/or intercrop maize, beans, and pumpkin varieties, and a few use no-till practices, whereas most practice conventional tillage using oxen or rented tractors (Kosgei et al. 2007). All farming is carried out by the farmers and their families. Some use artificial fertilizers and chemical pesticides. Okhombe is inhabited by approximately 1000 homesteads (6000 people), and Potshini approximately 400 homesteads (2000 people), sharing the grazing area of about 3000 and 800 ha, respectively. The communal grazing areas show clear evidence of land degradation related to soil erosion, gully formations, overgrazing, and compacted cattle pathways (Sonneveld et al. 2005, Kongo and Jewitt 2006, Salomon et al. 2013). Mainly cattle, but also some goats, are grazing in the communal grazing land, with few restrictions or little coordinated grazing management in place (Salomon 2011). Both communities evolved during the apartheid era when people were either forcefully allocated or prevented from moving or expanding because of racial segregation laws and associated land restrictions. The legacies of these discriminatory practices persist in terms of land access, education levels, and the distribution of wealth, development opportunities, and basic societal services, despite attempts by the government during the past 2 decades to amend the historical inequalities (Francis 2006, Thornton 2009, Smith et al. 2014).

The 10 commercial farmers are distributed in the surroundings of the towns of Bergville and Winterton; the 2 furthermost farms are approximately $49 \mathrm{~km}$ apart, and altitude ranges from 1065 to $1460 \mathrm{~m}$ above sea level. These farmers privately own on average 1600 ha each, which to a large extent has been inherited for generations. The average area of cropland among the 10 participating farmers is approximately 420 ha, of which $57 \%$ is irrigated. The presence of dams and large-scale irrigation systems provides opportunities for double cropping of summer and winter crops (Wesely 2010). Commercial croplands are characterized by large fields and high-intensive, mechanized monoculture (Wilk et al. 2013). Mainly genetically modified organism (GMO) seed is used, and most farmers follow similar application programs of artificial fertilizer and high use of chemical pesticides, often applied aerially. All commercial farmers practice no-tillage techniques, typically rotating maize and soya, often planting winter wheat (Wesely 2010), as well as winter cover crops for soil improvement and complementary winter grazing (Wilk et al. 2013). The commercial farmers also privately own on average about 1100 ha of grazing land, of which about $90 \%$ is uncultivated and predominantly used for grazing of cattle. Although commercial farmers also battle with erodibility of the sloping grasslands and gully formation, management practices, e.g., rotation of grazing camps and fencing off gullies, are in place to minimize the land degradation (Malinga et al. 2013). The commercial farms are important sources of employment for surrounding communities, both in terms of permanent and seasonal employment. Many of the 10 participating commercial farmers have present and previous farm employees and their families residing within the farm boundaries. 
Table 1. Overview of selected ecosystem services, variables used to quantify supply, and where data was obtained from.

\begin{tabular}{|c|c|c|c|}
\hline \multirow[t]{2}{*}{ Ecosystem Service } & \multirow[t]{2}{*}{ Variable(s) } & \multicolumn{2}{|c|}{ Data Obtained From } \\
\hline & & Smallholder & Commercial \\
\hline Crop production & Maize and bean production & $\begin{array}{l}\text { In-depth interviews and } \\
\text { participatory mapping }\end{array}$ & $\begin{array}{l}\text { In-depth interviews and } \\
\text { participatory mapping }\end{array}$ \\
\hline Crop variety & Number of different crops including vegetable gardens & & \\
\hline Livestock production & Number of cattle & & \\
\hline Wild foods & Collection of wild herbs and meat & & \\
\hline Building materials & Collection of building materials & & \\
\hline Firewood & Collection of firewood & & \\
\hline Traditional medicines & Collection of traditional medicines & & \\
\hline Cultural heritage & Sites important for cultural heritage and expression & & \\
\hline Recreation & Sites used for recreational activities & & \\
\hline Aesthetic value & Sites used for aesthetic appreciation & & \\
\hline Spiritual value & Sites with spiritual/religious importance & & \\
\hline Social relations & Sites used for social relations (meetings) & & \\
\hline Water availability & Infiltration, runoff, farming practices & $\begin{array}{l}\text { Publications of in situ } \\
\text { biophysical measurements, } \\
{ }^{\dagger} \text { GIS data, and interviews }\end{array}$ & $\begin{array}{l}\text { Private soil analysis reports, } \\
\text { GIS data, and interviews }\end{array}$ \\
\hline Water flow regulation & Infiltration, soil moisture, runoff, farming practices & & \\
\hline Soil erosion regulation & Slope, soil loss, C content, farming practices & & \\
\hline Nutrient retention & $\mathrm{C}$ content, $\mathrm{C} / \mathrm{N}$ ratio, soil nutrients, farming practices & & \\
\hline
\end{tabular}

\section{METHODS}

We developed a mixed-method approach to assess the varying nature of several different ecosystem services, as there exists no single comprehensive method that captures the wide range of services associated with agricultural landscapes (Taylor 2010). We combined in situ biophysical and social data, using participatory mapping, in-depth interviews, and expert assessment to quantify the supply and demand of ecosystem services in cropland and grazing land. This approach enabled assessment of the socialecological coproduction of ecosystem services, as well as the diversity of values attached to the services, which is crucial when assessing ecosystem services from a sustainability perspective (Pascual et al. 2017). The use of multiple data sources, combined with long-term field observations, not only assures capturing several social-ecological aspects of ecosystem services, but also serves as validation of the data.

The use of the terms "supply" and "demand" of ecosystem services within the scientific community is far from consistent (Villamagna et al. 2013, Wolff et al. 2015). Supply is most commonly mapped as the potential of a land unit to deliver ecosystem services based on land cover/land use, but which provides only hypothetical measures of ecosystem services (Egoh et al. 2012, Martínez-Harms and Balvanera 2012). Here, we aimed at assessing the actual supply rather than using proxies (Hein et al. 2006). The actual supply (hereby referred to as "supply") of the services water availability, water flow regulation, soil erosion regulation, and nutrient retention is estimated through a multicriteria expert assessment of previously collected biophysical data and information obtained through the in-depth interviews and mapping exercise. For the other services, the supply refers to the actual production, use, and/or appreciation of an ecosystem service from a given area, obtained through in-depth interviews and participatory mapping (see specifics of variables in Table 1 and more detail in the section Data collection).
The term "demand" is also used in the ecosystem literature in various ways (Wolff et al. 2015). Scholars may perceive demand as the actual use or consumption of a good or service (Burkhard et al. 2012) or as desires and preferences by societies and individuals (Wolff et al. 2015). We view demand as the latter, which corresponds to the perspective of demand defined by Daw et al. (2016) as "needs, gaps and aspiration." Here, we estimate the demand for the ecosystem services in relation to the supply (shortages or sufficiency), i.e., we do not aim to quantify demand with separate indicators but rather estimate whether the farmer groups perceive the supply of services to meet their demands. The ways in which the farmer groups benefit from the ecosystem services differ, as also discussed by Pascual et al. (2017), and will influence the expression of demand for those services. For example, the demand for crop production by the smallholder farmers relates to food to feed the family, whereas commercial farmers produce crops to sell. Although the commercial farmers also have demand for food, their direct benefit from crop production is for income generation.

\section{Ecosystem service selection}

The selection of ecosystem services for an assessment should be relevant to the context and meet the goals of the assessment (Malinga et al. 2013). The set of ecosystem services we selected was carefully chosen based on the following three criteria: (1) relevance to both smallholder and commercial farmers, informed by Malinga et al. (2013) where participatory scenario planning and expert assessments were conducted in the same study area aimed at identifying relevant ecosystem services; (2) representation of different service categories to help capture the multiple goals and dimensions of a multifunctional landscape (Lovell and Johnston 2009, Duraiappah et al. 2014, Hodbod et al. 2016); and (3) feasibility of collecting primary in situ data or availability of secondary data from the study area. The final selection included 16 ecosystem services, which contribute to the 
livelihoods and well-being of the farmer groups in various ways. Selected ecosystem services, variables, and how data were obtained are presented in Table 1. Table A1.1 (Appendix 1) describes in more detail how the services relate to the variables.

\section{Data collection}

\section{Participatory mapping and in-depth interviews}

To capture the intertwined social-ecological aspects of ecosystem services, integrated methods that combine disciplines and knowledge systems are needed (Lang et al. 2012, Diaz et al. 2015). We therefore conducted a participatory mapping exercise (Fagerholm et al. 2012, van Berkel and Verburg 2014) to identify and assess values and perceptions of the farmers, as well as sitespecific, high-resolution land-use information such as management practices, crop varieties, and local knowledge on species and ecosystems (Ryan 2011, Fagerholm et al. 2012, Plieninger et al. 2013, Sinare et al. 2016). We held in-depth interviews with each of the 20 farmers at their homes, lasting approximately $1 \mathrm{~h}$. Nine out of the 10 smallholder farmers were interviewed using an interpreter who translated between Zulu and English, with the rest in English. The interviews were semistructured according to an interview questionnaire combining open- and closed-ended questions (see Appendix 2 for interview guide). The interviews alternated questions and mapping exercises using preprinted A 2 or A 3 color satellite images of the farmer's landholdings sourced from Google Earth. The farmers drew their exact landholdings and marked out land uses and land cover, i.e., water bodies, natural vegetation, eroded waterways (gullies), crop fields, grazing areas, houses and buildings, and so forth. Crop types and yields, livestock types and numbers, farming practices, and irrigation methods were indicated on the map, as well as places for collection of wild foods, building materials, firewood, and traditional medicines. The farmers also marked out and answered questions about their use of places for recreational activities, social relations (meetings), aesthetic appreciation, sites with spiritual importance, and places that are valuable and used for cultural heritage. The questionnaire also included information on crop yield in a normal, dry, or wet year. Additionally, the farmers answered questions about whom they produce food for, i.e., family only, neighbors/nearby community, or the wider society; farm inheritance and ownership; farming skills and knowledge heritage; and their perspectives of the farmer's role and responsibility in society.

One farmer from the Potshini community, who has the role of community facilitator in research and development work and has insight into the community boundaries, marked out the communal grazing and village boundaries for Potshini. The boundaries for the Okhombe community were obtained from GIS layers compiled by Bangamwabo (2009). The spatial information from the participatory mapping exercise and in-depth interviews were synthesized and processed into GIS layers using QuantumGIS. Layers representing landholdings and land-use polygons were drawn, which were used for calculations of, e.g., areas, slope, and identification of soil types from available GIS layers.

Expert assessment of soil and water services

Numerous biophysical measurements have been collected throughout the two smallholder communities by a wide range of researchers from various disciplines over a long period of time.
We compiled published data, e.g., soil loss and infiltration (Table 1), and unpublished data, i.e., private soil analysis reports obtained from commercial farmers; available GIS data, e.g., slope and soil types; and relevant management practices used by the farmers (Table 1). The published data were obtained through consultations with researchers that are and have been active in the study area and through a review of published literature. For each farm and land-use polygon obtained from the participatory mapping exercise, we extracted data from the publications and/ or soil reports and included the relevant variables in a matrix (see Table 1 for overview and Table A1.2 in Appendix 1 for a more detailed description). Based on our collective expertise in relevant disciplines and topics, e.g., water resources management, sustainability science, and landscape ecology, and with extensive experience from the field study area, we then estimated the supply of the ecosystem services water availability, water flow regulation, erosion regulation, and nutrient retention by integrating several variables for each service (Table A1.2 provides a detailed overview of the variables, values, and criteria). In cases where data were missing for any of the variables for any of the farmers, we used extrapolations based on knowledge of farming practices, farming intensity, and land use among neighboring farms that we obtained from the in-depth interviews and participatory mapping, as well as long-term field observations.

\section{Data analysis and comparison}

Supply of ecosystem services

The varying nature of the underlying ecosystem service variables made it difficult to quantify the supply of services in the same way across all services. This required an explorative and novel approach to data analysis and comparison. This approach only allows comparison between the farmer groups and land uses, and not between different services. Some ecosystem services were expressed with an absolute number for a given land unit, e.g., crop production (tons/hectare), whereas others were ranked according to their importance in the household, e.g., firewood, or, when more elusive, expressed as either being used/appreciated or not, within a certain land use, e.g., spiritual meaning. To enable comparison between farmer groups and land uses, we expressed the relative value of the ecosystem service supply using either categorical or binary variables (Fig. 2). The supply of most of the services, i.e., crop production, crop variety, livestock production, wild foods, building materials, firewood, recreation, cultural heritage, water availability, water flow regulation, erosion regulation, and nutrient retention, was expressed using categorical variables, in five categories $(1,2,3$, 4, and 5; see Table A1.1 in Appendix 1 for category values and more detailed description of the data handling and analysis). The supply of the ecosystem services traditional medicine, social relation, spiritual value, and aesthetic appreciation was expressed using binary variables, where the values of the service supply were expressed as occurring (1) or not occurring (0). We expressed the values of these services as how many of the farmers in each farmer group use/appreciate that service in relation to the total number of farmers in that group. We expressed the supply values for each farmer group and for croplands and grazing lands, respectively.

Demand for ecosystem services in relation to supply

We further compared the ecosystem service supply with demand (Fig. 3), between the smallholder and the commercial farms. The 
Fig. 2. The supply of ecosystem services in smallholder and commercial agricultural land uses, cropland (a) and grazing land (b). The diagrams to the left show normalized values relative to 5, including standard deviation for categorical values. The tables on the right show the actual values and maximum values for each variable.

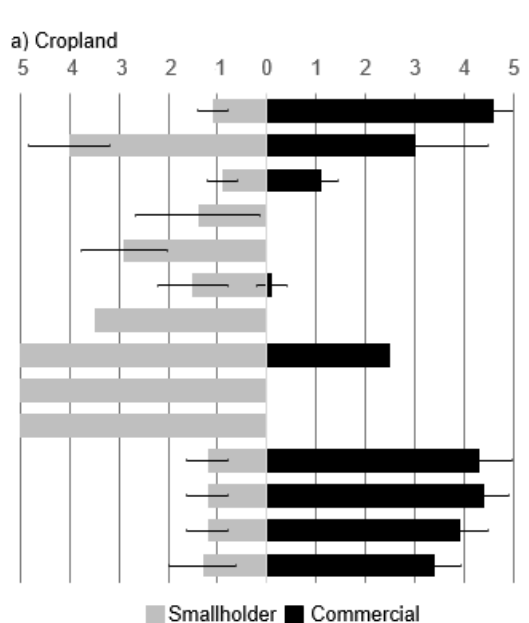

b) Grazing land

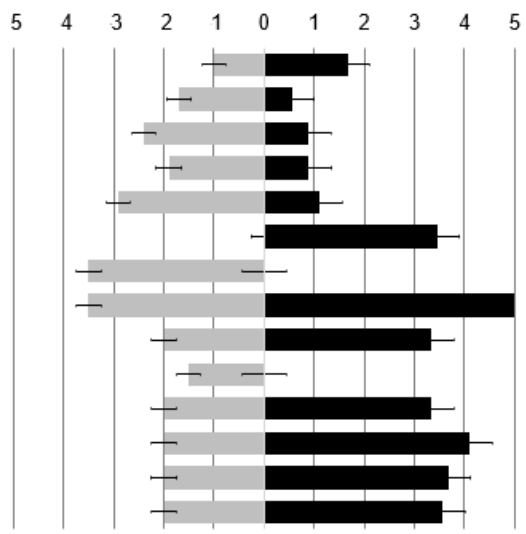

Crop production Crop variety Livestock production Wild foods Building material Cultural heritage Traditional medicine Aesthetic Spiritual/religious Social relations Water availability Water flow regulation Erosion regulation Nutrient retention Livestock production Wild foods Building material Fire wood Cultural heritage Recreation Traditional medicine Aesthetic Spiritual/religious Social relations Water availability Water flow regulation Erosion regulation Nutrient retention

\begin{tabular}{|c|c|c|c|}
\hline Variables, unit & $\begin{array}{l}\text { Small- } \\
\text { holder }\end{array}$ & $\begin{array}{l}\text { Commer- } \\
\text { cial }\end{array}$ & Max \\
\hline Size of cropland, hectares-average & $1.87^{\star}$ & 419.3 & 1100 \\
\hline Production of maize (beans), tons/hectares-average & $1.79(0.35)$ & $10.84(3.76)$ & $14(4.6)$ \\
\hline Number of different crops and vegetables-average & 9.6 & 6.6 & 13 \\
\hline Number of cattle grazing in winter $r^{* \star}$-average & 9.4 & 822.2 & 2480 \\
\hline Importance of collecting wild foods_-average & 1.4 & 0 & 5 \\
\hline Importance of collecting building material-average & 2.9 & 0 & 5 \\
\hline Number of places or species for cultural heritage-average & 2.4 & 0.1 & 8 \\
\hline Number of farmers collecting traditional medicine & 7 & 0 & 10 \\
\hline Number of farmers expressing aesthetic appreciation & 10 & 5 & 10 \\
\hline Number of farmers using land for spiritual/religious meaning & 10 & 0 & 10 \\
\hline Number of farmers using places for social relations & 10 & 0 & 10 \\
\hline Infiltration, runoff, farming practices-average & 1.2 & 4.3 & 5 \\
\hline Infiltration, soil moisture, runoff, farming practices-average & 1.2 & 4.4 & 5 \\
\hline Slope, soil loss, C content, farming practices_-average & 1.2 & 3.9 & 5 \\
\hline $\mathrm{C}$ content, $\mathrm{C} / \mathrm{N}$ ratio, soil nutrients, farming practices-average & 1.3 & 3.4 & 5 \\
\hline Variables, unit & $\begin{array}{l}\text { Small- } \\
\text { holder }\end{array}$ & $\begin{array}{l}\text { Commer- } \\
\text { cial }\end{array}$ & Max \\
\hline Size of grazing land, hectares-average & $15^{\star \star \star}$ & 1134.3 & 2102 \\
\hline Number of cattle grazing in summer ${ }^{* *}$-average & 9.4 & 822.2 & 2480 \\
\hline Importance of collecting wild foods_-average & 1.7 & 0.56 & 5 \\
\hline Importance of collecting building material-average & 2.4 & 0.89 & 5 \\
\hline Importance of collecting firewood-average & 1.9 & 0.89 & 5 \\
\hline Number of places or species for cultural heritage-average & 5.4 & 1.44 & 8 \\
\hline Number of recreation activities-average & 0 & 3.89 & 6 \\
\hline Number of farmers collecting traditional medicine & 7 & 0 & 10 \\
\hline Number of farmers expressing aesthetic appreciation & 7 & 10 & 10 \\
\hline Number of farmers using land for spiritual/religious meaning & 4 & 6 & 10 \\
\hline Number of farmers using places for social relations & 3 & 0 & 10 \\
\hline Infiltration, runoff, farming practices-average & 2 & 3.33 & 5 \\
\hline Infiltration, soil moisture, runoff, farming practices-average & 2 & 4.11 & 5 \\
\hline Slope, soil loss, C content, farming practices-average & 2 & 3.67 & 5 \\
\hline $\mathrm{C}$ content, $\mathrm{C} / \mathrm{N}$ ratio, soil nutrients, farming practices-average & 2 & 3.56 & 5 \\
\hline
\end{tabular}

*The average size of the crop fields managed by the smallholder farmers who participated in the study.

**The bars in the diagram to the left indicate the number of cattle divided in summer and winter months as they graze in the grazing lands in summer and croplands in winter (see Table A1.1 in Appendix 1 for further explanation). The number of cattle in the tables to the right shows the average of the total number of cattle owned by the farmers.

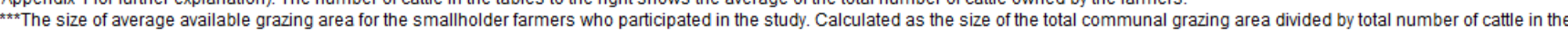
communities

supply values from Figure 2 were converted to be expressed as low, medium, or high. To do this, we altered the average categorical and binary variables to three categories: low $=0 \%$ to $32 \%$ of maximum, medium $=33 \%$ to $65 \%$, and high $=66 \%$ to $100 \%$. The demand for the ecosystem services was determined qualitatively by analyzing descriptions and narratives obtained through the interviews. Statements and expressions made, or stories told, by the farmers were analyzed as shortages, sufficiency, or surplus in relation to the supply, i.e., whether the farmers perceived that the supply of a service met their demand. For each farmer and each service, the collected statements and expressions were taken into account and estimated as low, medium, or high. For example, if a farmer expressed low interest in recreation, the demand by that farmer for that ecosystem service was estimated to be low. If a farmer expressed concern with insufficient yield, the demand for crop production was thus estimated to be high for that farmer. The estimates by all respondents within the farmer group were then combined, and a value of low, medium, or high was assigned for the farmer group for each service.
The farmers' capacity to maintain supply and meet demand For the analysis of the capacity of the farmers to maintain supply and meet the demand, we used a multicriteria estimate based on a combination of biophysical and socioeconomic factors. Biophysical factors are related to the condition of the land, which to a large degree corresponds to the supply of the ecosystem services water availability, water flow regulation, erosion regulation, and nutrient retention. High supplies of the water and soil ecosystem services thus contribute to a higher capacity of the farmers to manage ecosystem services. Socioeconomic and cultural factors are financial capacity, infrastructure and technical equipment, skills, and landownership and authority of the land, which all will influence the capacity of farmers to maintain supply of services and meet their demands. Communal lands that are used not by individual landowners, but by the collective under traditional authority therefore imply lower capacity (agency) by individual farmers to manage. Low financial strength (high levels of poverty) combined with lack of skills will inevitably exacerbate the incapacity to produce sufficient yields 
Fig. 3. Comparison between smallholder (a) and commercial (b) agricultural landscapes (cropland and grazing land combined) in terms of the supply of 16 ecosystem services (x-axis: low, medium, and high), the demand thereof (y-axis: low, medium, and high), and the capacity of the farmer groups to maintain the supply and meet the demand (color of box: low = dark red; medium = pink; and high $=$ light pink).

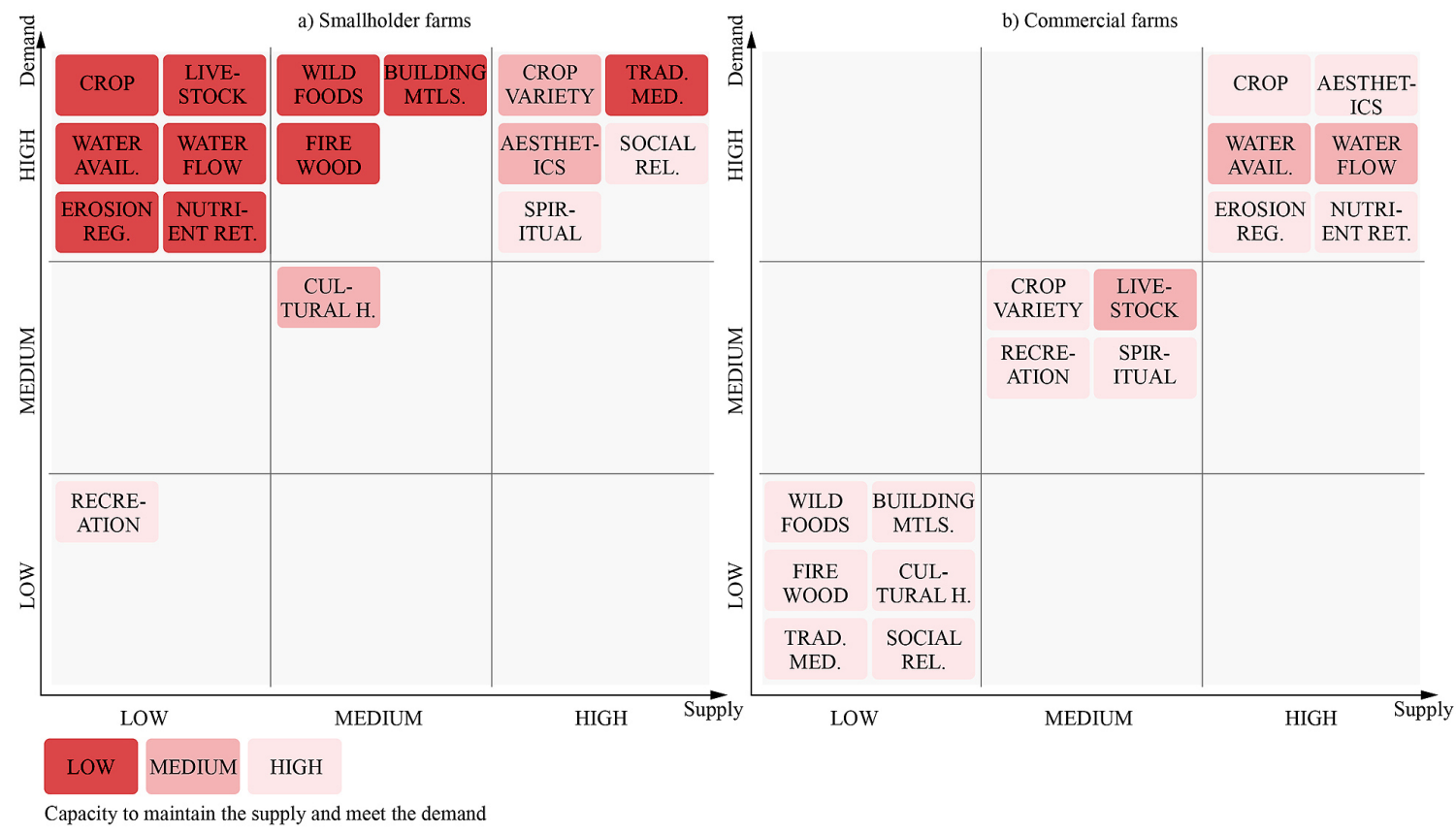

on croplands that are nutrient poor and with low water availability. Table A1.3 in Appendix 1 provides a detailed description of the factors used for each ecosystem service to estimate the farmer groups' capacity to influence the ecosystem service generation. The capacity was expressed as low, medium, or high.

\section{RESULTS}

\section{Supply of ecosystem services}

The smallholder and commercial agricultural landscapes provided starkly different ecosystem service outcomes (Fig. 2). The differences were especially large in terms of agricultural production, i.e., crop and livestock. Commercial farmers had considerably higher agricultural production and much higher supply of soil- and water-related ecosystem services than smallholder farmers. Crop production is on average about 6 times higher per hectare in the commercial croplands than in the smallholders' croplands, and the area used for crops is more than 200 times larger. Noncultivated provisioning services such as wild food, building materials, and firewood were collected to a higher degree by smallholder farmers. These services were also used and appreciated in the commercial grazing landscapes, but, as mentioned by the farmers, almost exclusively by farm staff rather than themselves. Similarly, spiritual value in the commercial landscapes was mostly connected to staff, primarily manifested as family and ancestral graves in the grazing lands. In smallholder croplands, the spiritual sites were predominantly connected to graves situated mainly by the crop fields in the homesteads. In the communal grazing lands, there were some sites used for praying, especially during periods of drought. Aesthetic appreciation by commercial farmers was mostly connected to grazing areas, while more evenly distributed across both land uses by smallholder farmers. Three ecosystem services were supplied exclusively in either smallholder or commercial landscapes. Places for social relations (meetings), and the collection of traditional medicines, were only valued in smallholder landscapes, and recreation had value only to commercial farmers (Fig. 2).

\section{Demand for ecosystem services in relation to supply}

When it comes to demand for ecosystem services, the commercial farmers did not express insufficient supply of any of the assessed ecosystem services, which is why they were considered to meet their demand for all services (Fig. 3b). The supply of ecosystem services through commercial agriculture was expressed by the farmers to be enough to maintain a lifestyle that the farmers had chosen, primarily through its income generating benefits, but also from the direct use of the landscape. Smallholder farmers used their lands largely for subsistence. Their demand for most ecosystem services was generally higher than the supply (Fig. 3a).

Cultural heritage value was articulated in contrasting ways in the two farmer groups. Commercial farmers mentioned mainly cultural-historic heritage in the form of remnants from previous people's use of ecosystem services within their grazing lands, such as rock paintings, stone kraal ruins, historical mining sites, and fossils. The supply was relatively low compared with smallholder landscapes, and many commercial farmers expressed rather low 
demand for, or attachment to, the service as manifested by the following quote from one of the commercial farmers:

\begin{abstract}
There are some hundred year old stone house ruins and ancient stone kraal ruins on my farm, but if I need the stones or if they are in my way I will remove them. They are not that valuable to me.
\end{abstract}

Smallholder farmers actively use the landscape, both grazing land and cropland, for carrying out cultural ceremonies and rituals, as well as for collection or production of species used in cultural traditions, traditional attire, and handicrafts. The demand for these services is, however, decreasing along with shifting values of the people in the smallholder communities (also found in Malinga et al. 2013), and many smallholder farmers expressed that the cultural heritage-related services used to be more important to the community when they were young. Many of the natural products traditionally used to express the connection with their culture are gradually being replaced with synthetic materials; for example, skirts traditionally made with cow skin and used in traditional ceremonies are increasingly made with fabric.

The ecosystem service social relations, i.e., places for meetings, was widely used and appreciated by smallholder farmers and was therefore considered to be in high demand and met by a high supply (Fig. 3a). Smallholder farmers had frequent meetings with, e.g., peer groups, community members, and leaders, at various sites distributed within the communal lands and villages, typically under a solitary tree or a grove providing shade. Specific places served the purpose of different kinds of organizational assemblies, as described by a smallholder farmer:

The leaders in the community meet under the tree up the hill towards the grazing land, and when the warriors [ the men $]$ get together for a ceremony we usually meet by the corner of the trial sites [a fenced area for research experiments]. Meetings with information for the entire community take place under the grove by the river towards the wetland.

It was only in the smallholder landscapes that overall demand for ecosystem services was higher than supply. Smallholders' crop production is an example where the supply was low and the demand high. A smallholder farmer expressed the relationship like this:

Usually our harvest [of maize] lasts until October. In a good year we don't have to buy maize flour until December, and in a bad year we have to buy it already in August.

The collection of firewood is an ecosystem service that was of medium supply in smallholder landscapes, whereas the demand for it was higher. This smallholder farmer had a similar view on the availability of firewood as many others:

We mainly use fire wood for cooking. We have electricity these days but it is too expensive to use for cooking. We only collect some of the fire wood ourselves because the trees are almost finished. Some people who can't afford to buy fire wood will collect it, but they have to walk very far and can spend the whole day searching. Those who live closer to the woods are lucky.

\section{The farmers' capacity to maintain supply and meet demand}

The smallholder farmers' capacity to maintain supply and meet demand was generally low for most of the ecosystem services (Fig. $3 a)$. Where the capacity was high, for example social relations and spiritual values, the services per se were not particularly dependent on management practices or economic strength. The commercial farmers' capacity to maintain supply is predominantly high (Fig. $3 b)$. In terms of water availability and water flow regulation, the capacity was considered medium because of climatic factors, e.g., rainfall, that mostly lie beyond the control of the farmers.

\section{DISCUSSION}

We explored and quantified the differences in ecosystem service coproduction between smallholder and commercial agricultural landscapes located adjacent to one another. Farm-level assessment of a wide range of services illustrated considerable differences between the landscapes, both in terms of supply of services and how they met farmers' demand for services. The income from food production services and private access to large tracts of land allow commercial farmers flexibility in choices of lifestyles and provide a means to maintain or enhance the supply of prioritized services. For most of the ecosystem services we assessed, commercial farmers had a high capacity to influence the supply of services and to meet their demand. On the contrary, smallholder farmers' capacity to meet their demand for most of the ecosystem services was low. The approach we developed highlights the complexity in assessing ecosystem services that clearly have different benefits and values to different user groups, living in landscapes strongly shaped by a variety of socioeconomic and biophysical factors. The ditch described in the introduction constituting the border between the two agricultural landscapes symbolizes a distinct divide between farmer groups' realities (Fig. 1). This divide is manifested in the ways in which different groups benefit from, and value, certain ecosystem services (Daw et al. 2011, Pascual et al. 2017). The commercial farmers in this study benefit economically from their crop and livestock production while producing food primarily for other people. Many of the values of ecosystem services of the commercially farmed landscape are thus mediated by markets and money, and by offering employment for other beneficiaries, they also extend some of these benefits to nonowners. Crop production in smallholder areas is an ecosystem service that directly feeds the farmers and their families but does not reach other beneficiaries. Similar to the findings of Wilk et al. (2013), only a few smallholder farmers produce a surplus to sell to neighbors, typically only during the better years. The smallholder communities' food demand can only be met by buying food produced elsewhere and to a small and varying degree is complemented by harvesting wild foods from communal lands. Noncultivated provisioning services, such as wild foods, building materials, firewood, and traditional medicines, had much higher importance for smallholder than for commercial farmers. Other studies from Russia, Ukraine, and Sweden (Stryamets et al. 2015) and South Africa (Hamann et al. 2015) show similar results that economic development influences the consumption of and dependence on these services. Typically, smallholder farmers hold cattle for reasons other than food production; cattle have high cultural value as well as being an economic asset and insurance, as also seen in Sinare et al. (2016).

The field of ecosystem service science is currently seeing a rapid development of robust methods to capture and quantify the value of less tangible ecosystem services such as recreation, spiritual, and 
cultural heritage (e.g., Ryan 2011, Milcu et al. 2013, BerbésBlázques et al. 2016). These new frameworks are grounded in previous conceptualizations of ecosystem services but emphasize the need to approach valuation of ecosystem services from different cultural perspectives, e.g., the UK National Ecosystem Assessment (Church et al. 2014) and the Intergovernmental Science-Policy Platform on Biodiversity and Ecosystem Services (Diaz et al. 2015). Within this discourse, relational values seem particularly relevant for studies of multiple and interacting services where emergent values have diverse roots and expressions (Chan et al. 2016). Relational values complement the dominating approaches to assess and quantify ecosystem services, namely, instrumental and intrinsic values (cf. Chan et al. 2016) by including people's individual and collective relationships and responsibilities into how they frame and value nature. This is particularly relevant in an area such as the Upper Thukela where the landscape consists of a complex mix of individual and collective, formal and informal land tenure systems, as well as socio-cultural and religious connections to nature. However, although recognizing the validity of these approaches, this study was designed with consideration given to the constraints that inevitably come with an assessment that involves the collection of in situ data for a large number of services. Our approach identified and measured the number of recreational activities, places with spiritual importance, and species used or places at which there is a cultural heritage connection, respectively. This enabled comparison of the diversity of opportunities but disregarded the fact that a person can attach a very high value to one single recreation activity or place for spiritual meaning or cultural heritage, whereas others may ascribe only a little value to each of several different activities. This comparability can be deceptive though; the way respondents related to the cultural ecosystem services had different meanings and value for commercial and smallholder farmers. Commercial farmers explicitly said they use their grazing lands for recreational activities, and these are only available to the farmers themselves, their families, and invited friends. The smallholder farmers responded unanimously that they do not carry out any activities for the purpose of "recreation." However, they did state that they got exercise from walking in their landscapes, as this is the only or primary mode of transport. This aspect of cobenefits or qualitative nuance was not captured by the service recreation as we framed it.

Landscape multifunctionality is decided by both environmental conditions and socioeconomic settings. Social-ecological circumstances determine the landscape potential for supporting multiple environmental, economic, and social goals, and these need to be considered in an assessment of a landscape's multifunctionality. Differences and unequal opportunities between the farmer groups exist in almost all aspects of the coproduction of ecosystem services: the farmers' ability to access soil and water, human skills, technology and infrastructure, and socio-cultural organization and institutions at various levels. Institutions often operate and influence ecosystem service coproduction at long temporal scales, which often means that legislation and policies aiming at amending inequities lag behind. Assessments that do not consider historically determined and inequitable inclusion in decision making, resource distribution, and access might miss crucial factors influenced by power relations, which shape the use, appreciation, and access to the benefits derived from ecosystem services (Berbés-Blázquez et al. 2016). Before we discuss the multifunctionality of the different agricultural landscapes, we must therefore go back in time and consider how these contrasted and inequitable landscapes emerged.

Population groups in South Africa with ethnicities other than whites with European origin were historically not allowed to own land. Smallholder communities such as the Zulu communities in the Upper Thukela were restricted to marginal and vulnerable lands with less fertile soils and higher slopes and altitudes, whereas the descendants of European settlers appropriated land most suitable for agriculture and vast land areas (Percival and HomerDixon 1998). The agricultural practices of these farms intensified along with global trends and advancements and shifted from the subsistence of individual families to increasingly commercial (farmers' statements). Although commercial farmland was inherited within families for generations, or sold to other commercial farmers, the populations in the smallholder communities grew rapidly, and the land they had access to could not expand. Land degradation and decreased soil quality became reality on both sides of the ditch, because of high population densities in the smallholder communities, poverty, and subsequent increased pressure on the communal lands (Percival and Homer-Dixon 1998, Hoffman and Todd 2000, Francis 2006), and because of rapid intensification in the commercial farmland. Mechanization, GMO crops, and increased knowledge on soil erosion regulation and soil conservation among commercial farmers over the past decades resulted in implementation of notill practices, crop rotation, cover cropping, and grazing rotation and led to substantial improvement in soil conditions and productivity (farmers' statements).

Simultaneously, the situation in the smallholder communities in the Upper Thukela has evolved rather differently. The historical aspects in these areas, along with, for example, lack of opportunities for education and employment, as argued by Boonstra and de Boer (2014) are likely to manifest a persistent path dependency, initially kept in place by racial discrimination laws. High population densities in the smallholder areas in combination with poverty, insufficient soil and water resources management, and low food production increase the pressure on the communal lands, degrading lands and depleting the common resources (Pollard et al. 2014). Financial capacity to buy, for instance, building material and firewood, decreases, which further exacerbates the gap between the supply and demand of the common-pool ecosystem services. An evidently unsustainable system like this, reinforced by strong social and ecological feedback loops, is commonly referred to as a poverty trap (Enfors and Gordon 2008, Boonstra and de Boer 2014, Haider et al. 2018). Poor, low-producing smallholder farmers, such as those in the Potshini and Okhombe communities, are confined by a lack of capacity to enhance the supply of ecosystem services to meet their needs. Escaping a poverty trap, from a social-ecological perspective, requires breaking the reinforcing feedbacks and creating and strengthening new and desirable feedbacks (Haider et al. 2018). To propose a robust solution to exit a poverty trap as demonstrated in this study area, more research is needed on the interactions between the social and ecological feedback loops, at different and interacting spatial and temporal scales, as well as 
analysis of the systems' path dependency (Lade et al. 2017, Haider et al. 2018). However, we suggest that a poverty trap is underpinned by more than financial and capacity constraints, which are common aspects targeted in strategies to escape these. This means that attempts to alleviate poverty through financial aid, e.g., subsidies or credit, or capacity building, e.g., skill development and training, are likely to either be insufficient, fail, or even further exacerbate poverty (Green and Hulme 2005). For example, initiatives facilitated by external organizations to implement innovations within Potshini and Okhombe, with the aim of improving soil conditions, food security, livelihoods, and grassland rehabilitation through, for instance, no-tillage and conservation agriculture practices and grazing rotation schemes have had limited success (Sturdy et al. 2008, Salomon 2011, Smith et al. 2014). Although studies have shown success in, e.g., increased yield (comparable with that of the commercial systems), reduced runoff and soil loss, and grassland rehabilitation (Kongo and Jewitt 2006, Kosgei et al. 2007, Dlamini et al. 2011, Mchunu et al. 2011, Mansour et al. 2013), when projects ended and the implementing organizations left, the innovations were discontinued by the participants despite documented positive effects (Sturdy et al. 2008). This shows the need for a deeper understanding of the factors that restrict long-term adoption of innovations and for new approaches for the introduction of management practices intended to deliver sustainable benefits and opportunities to escape poverty traps.

As suggested by Lade et al. (2017), "the diverse dynamics that arise from the different relationships between agricultural production, environmental degradation, and cultural aspects of rural communities call for diverse alleviation strategies." The high population density and the pressure on the communal land areas for livestock grazing and harvest of building materials, firewood, and wild foods indicate that one component of the diverse strategies for upliftment of the smallholder communities would be to increase the access to land, specifically to land suitable for agricultural production. Communities such as Potshini and Okhombe are constrained by both national and local institutions and land distribution legislation. Inequitable power structures in communities under traditional authority are manifested through both formal and informal agreements and kinship networks that influence community members' access to land and natural resources within the community boundaries. Powerful actors have an advantage over the impoverished, and women often lack any opportunity to control and manage land (Cousins 2009). At a national level, land reform policies and efforts have remained a contentious issue since South Africa's transition to democracy (Benjaminsen et al. 2006). Neither the Land Restitution Policy, to return land to people who lost land because of racial discrimination; the Land Redistribution Policy, to redistribute private farm land and state land to previously landless and disadvantaged people; nor the Land Tenure Reform, to secure land tenure rights to black and colored South Africans, have met the targets that were set out during the first years of transition. The ongoing debate and framing of land policies will determine the future of the agricultural landscapes and smallholder communities in South Africa. To escape the poverty trap, a combination of land reform, financial support and increased skills, and knowledge and power to implement individual and collective practices to achieve sustainable agriculture is needed.
So, how do the diverse benefits and values, the historical inequity, social-ecological poverty traps, and land tenure relate to multifunctionality? An agricultural landscape producing multiple ecosystem services while sustaining food security and livelihoods for multiple beneficiaries without compromising future productivity could be seen as multifunctional, i.e., providing and maintaining environmental, social, and economic functions to meet multiple needs of society (Hodbod et al. 2016). Large-scale commercial agriculture is often associated with low multifunctionality, as large tracts of land are used for monoculture, at the cost of other services (Foley et al. 2005). Lowintensive, diverse, and heterogeneous agriculture landscapes are, on the other hand, often considered more sustainable (Kremen and Miles 2012). Although this analysis indicates a more diversified use of croplands among smallholder than commercial farmers, there is a more complex reality within the two types of agricultural landscapes in this study area. At a larger spatial scale, i.e., the functional scale of the landowner, it can be argued that the commercial landscape also meets many of the criteria of multifunctionality. There is an overall high production of food, most of the land is managed to reduce land degradation, and the landscape provides employment opportunities and benefits to various beneficiaries in multiple ways. However, private ownership means exclusive access to the landscape and its resources, thus reducing the availability of potential benefits for beneficiaries other than the landowners. Furthermore, although most commercial farmers tend to manage their grazing lands successfully and practice methods to improve the soil quality and reduce soil loss, there are still management practices in use that seriously compromise ecological processes and biodiversity (Dale et al. 2000), thus limiting future productivity. The extensive use of pesticides on large tracts of monoculture cropland is detrimental to waterways, wildlife, diversity of flora and fauna, and soil biodiversity (Dale et al. 2000, Hole 2005), especially in cases where pesticides are applied by air. This reduces the longterm sustainability of these management practices. Some of the commercial farmers label themselves as conservationists and experience conflicts in management decisions, as also highlighted by Henle et al. (2008). Although being aware of the risks caused by the use of pesticides, the farmers express that they feel that they have very little choice if they are to maintain or increase yield. The dominance of pesticide use in agriculture can be referred to as a technical lock-in, a kind of trap created by dependence on technical inputs such as pesticides within a system (Cowan and Gunby 1996), which will compromise increased multifunctionality in these systems. In contrast, the smallholder cropping landscape provides a fine-scale mosaic of small crop fields (Fig. 1), field margins and edges with natural vegetation, and patches of grass that are often abandoned crop fields, and with very limited use of pesticides. Some parts of the landscape thus provide opportunities for biodiversity, pollination, and biological pest control, whereas other areas present severe land degradation, overexploitation of resources, and underprovision of food.

The social, cultural, political, and historical complexity in these systems makes analysis of multifunctionality difficult, as we have shown. However, failing to consider and address these factors in policies that promote multifunctionality means that areas such as the Upper Thukela will remain with large injustices and 
inequalities and will feature predominantly unsustainable agricultural landscapes.

\section{CONCLUSION}

We studied smallholder and large-scale commercial farmers in the South African Drakensberg and how the supply of and demand for 16 ecosystem services in their agricultural landscapes varied as a result of management practices, farming intensities, farming cultures, and access to land. While commercial farmers, who produce large quantities of food, cater to the demands of beneficiaries both within and outside of the landscapes they manage, smallholder farmers experience low yields, land degradation, and overexploitation of communal grazing lands. Although both of these landscapes, to various degrees, can be seen as multifunctional, the smallholder and commercial farmers are facing different challenges in producing the complete sets of environmental, social, and economic goals of a multifunctional landscape. Embedded in the landscape are vast inequities originating from historical discrimination laws, and, because of their lack of access to land and natural, financial, and technical resources, smallholder communities risk remaining trapped in poverty. Solutions and forward thinking need to be cognizant of the past, and policies that aim at promoting multifunctionality without addressing inequity and poverty, and the socioeconomic and cultural complexities related to land tenure, would thus be misdirected in a South African context, and in an area like the Upper Thukela. Thus, one important step toward successful achievement of multifunctional, equitable, and sustainable agriculture is the development of national, but still situation sensitive and cross-sectoral development strategies.

Responses to this article can be read online at: http://www.ecologyandsociety.org/issues/responses. php/10380

\section{Acknowledgments:}

We thank two anonymous reviewers for their valuable contributions to this manuscript. Funding for the research was received by the Swedish Research Council Formas and the Bolin Centre for Climate Research, the Marianne and Marcus Wallenberg Foundation, and Mistra for core funding of the Stockholm Resilience Centre. We are thankful to all farmers who kindly availed themselves to participate in this study. We also thank Vincent Chaplot and Charmaine Mchunu for advice on soil variables. We thank Rutger Wielenga for invaluable assistance on the GIS work; Monique Salomon for feedback on the questionnaire and data presentation; Victor Bangamwabo for providing GIS layers; Michael Malinga for translation of the questionnaire; Nicholas Madondo, Nonhlanhla Mthembu, and Celiwe Masengemu for field assistance and translations of the interviews; and the Dladla family in Potshini and the Shezi family in Okhombe for accommodation and hospitality. We highly appreciate the comments received from A. Norström and T. Daw on an earlier version of this manuscript.

\section{LITERATURE CITED}

Andersson, E., and R. Lindborg. 2014. Species richness and assemblages in landscapes of different farming intensity - time to revise conservation strategies? PLoS ONE 9(10):e109816. http://dx.doi.org/10.1371/journal.pone.0109816

Andersson, E., B. Nykvist, R. Malinga, F. Jaramillo, and R. Lindborg. 2015. A social-ecological analysis of ecosystem services in two different farming systems. Ambio 44(S1):102-112. http://dx.doi.org/10.1007/s13280-014-0603-y

Bangamwabo, V. 2009. Spatial and temporal extent of land degradation in a communal landscape of KwaZulu-Natal, South Africa. Thesis. University of KwaZulu-Natal, Pietermaritzburg, South Africa.

Benjaminsen, T. A., R. Rohde, E. Sjaastad, P. Wisborg, and T. Lebert. 2006. Land reform, range ecology, and carrying capacities in Namaqualand, South Africa. Annals of the Association of American Geographers 96(3):524-540. http://dx.doi.org/10.1111/ j.1467-8306.2006.00704.X

Bennett, E. M., W. Cramer, A. Begossi, G. Cundill, S. Díaz, B. N. Egoh, I. R. Geijzendorffer, C. B. Krug, S. Lavorel, E. Lazos, L. Lebel, B. Martín-López, P. Meyfroidt, H. A. Mooney, J. L. Nel, U. Pascual, K. Payet, N. P. Harguindeguy, G. D. Peterson, A.-H. Prieur-Richard, B. Reyers, P. Roebeling, R. Seppelt, M. Solan, P. Tschakert, T. Tscharntke, B. L. Turner II, P. H. Verburg, E. F. Viglizzo, P. C. L. White, and G. Woodward. 2015. Linking biodiversity, ecosystem services, and human well-being: three challenges for designing research for sustainability. Current Opinion in Environmental Sustainability 14:76-85. http://dx.doi. org/10.1016/j.cosust.2015.03.007

Berbés-Blázquez, M., J. A. González, and U. Pascual. 2016. Towards and ecosystem services approach that addresses social power relations. Current Opinion in Environmental Sustainability 19:134-143. http://dx.doi.org/10.1016/j.cosust.2016.02.003

Bindraban, P. S., and R. Rabbinge. 2012. Megatrends in agriculture - views for discontinuities in past and future developments. Global Food Security 1(2):99-105. http://dx.doi. org/10.1016/j.gfs.2012.11.003

Björklund, J., K. E. Limburg, and T. Rydberg. 1999. Impact of production intensity on the ability of the agricultural landscape to generate ecosystem services: an example from Sweden. Ecological Economics 29(2):269-291. http://dx.doi.org/10.1016/ S0921-8009(99)00014-2

Boonstra, W. J., and F. W. de Boer. 2014. The historical dynamics of social-ecological traps. Ambio 43:260-274. http://dx.doi. org/10.1007/s13280-013-0419-1

Burkhard, B., F. Kroll, S. Nedkov, and F. Müller. 2012. Mapping ecosystem service supply, demand and budgets. Ecological Indicators 21:17-29. http://dx.doi.org/10.1016/j.ecolind.2011.06.019

Chan, K. M. A., P. Balvanera, K. Benessaiah, M. Chapman, S. Díaz, E. Gómez-Baggethun, R. Gould, N. Hannahs, K. Jax, S. Klain, G. W. Luck, B. Martín-López, B. Muraca, B. Norton, K. Ott, U. Pascual, T. Satterfield, M. Tadaki, J. Taggart, and N. Turner. 2016. Why protect nature? Rethinking values and the 
environment. Proceedings of the National Academy of Sciences of the United States of America 113(6):1462-1465. http://dx.doi. org/10.1073/pnas. 1525002113

Church, A., R. Fish, R. Haines-Young, S. Mourato, J. Tratalos, L. Stapleton, C. Willis, P. Coates, S. Gibbons, C. Leyshon, M. Potschin, N. Ravenscroft, R. Sanchis-Guarner, M. Winter, and J. Kenter. 2014. UK national ecosystem assessment follow-on. Work package report 5: culturalecosystem services andindicators. United Nations Environment World Conservation Monitoring Centre, Living With Environmental Change, Cambridge, UK. [online] URL: http://uknea.unep-wcmc.org/LinkClick.aspx?fileticket= $\underline{10 \% 2 \mathrm{fZhq} \% 2 \mathrm{bgwtc} \% 3 \mathrm{~d} \& \text { tabid }=82}$

Cousins, B. 2009. Potentials and pitfalls of "communal" land tenure reform: experience in Africa and implications for South Africa. In World Bank Conference on Land Governance in Support of the MDGs Responding to New Challenges. World Bank, Washington D.C., USA. [online] URL: http://siteresources. worldbank.org/INTIE/Resources/B Cousins.doc

Cowan, R., and P. Gunby. 1996. Sprayed to death: path dependence, lock-in and pest control strategies. Economic Journal 106(436):521-542. http://dx.doi.org/10.2307/2235561

Dale, V. H., S. Brown, R. A. Haeuber, N. T. Hobbs, N. Huntly, R. J. Naiman, W. E. Riebsame, M. G. Turner, and T. J. Valone. 2000. Ecological principles and guidelines for managing the use of land. Ecological Applications 10:639-670. http://dx.doi. org/10.1890/1051-0761(2000)010[0639:EPAGFM]2.0.CO;2

Daw, T., K. Brown, S. Rosendo, and R. Pomeroy. 2011. Applying the ecosystem services concept to poverty alleviation: the need to disaggregate human well-being. Environmental Conservation 38:370-379. http://dx.doi.org/10.1017/S0376892911000506

Daw, T. M., C. Hicks, K. Brown, T. Chaigneau, F. JanuchowskiHartley, W. Cheung, S. Rosendo, B. Crona, S. Coulthard, C. Sandbrook, C. Perry, S. Bandeira, N. A. Muthiga, B. SchulteHerbrüggen, J. Bosire, and T. R. McClanahan. 2016. Elasticity in ecosystem services: exploring the variable relationship between ecosystems and human well-being. Ecology and Society 21(2):11. http://dx.doi.org/10.5751/ES-08173-210211

DeClerck, F. A. J., S. K. Jones, S. Attwood, D. Bossio, E. Girvetz, B. Chaplin-Kramer, E. Enfors, A. K. Fremier, L. J. Gordon, F. Kizito, I. Lopez Noriega, N. Matthews, M. McCartney, M. Meacham, A. Noble, M. Quintero, R. Remans, R. Soppe, L. Willemen, S. L. R. Wood, and W. Zhang. 2016. Agricultural ecosystems and their services: the vanguard of sustainability? Current Opinion in Environmental Sustainability 23:92-99. http:// dx.doi.org/10.1016/j.cosust.2016.11.016

Díaz, S., S. Demissew, J. Carabias, C. Joly, M. Lonsdale, N. Ash, A. Larigauderie, J. R. Adhikari, S. Arico, A. Báldi, A. Bartuska, I. A. Baste, A. Bilgin, E. Brondizio, K. M. A. Chan, V. E. Figueroa, A. Duraiappah, M. Fischer, R. Hill, T. Koetz, P. Leadley, P. Lyver, G. M. Mace, B. Martin-Lopez, M. Okumura, D. Pacheco, U. Pascual, E. S. Pérez, B. Reyers, E. Roth, O. Saito, R. J. Scholes, N. Sharma, H. Tallis, R. Thaman, R. Watson, T. Yahara, Z. A. Hamid, C. Akosim, Y. Al-Hafedh, R. Allahverdiyev, E. Amankwah, S. T. Asah, Z. Asfaw, G. Bartus, A. L. Brooks, J. Caillaux, G. Dalle, D. Darnaedi, A. Driver, G. Erpul, P. EscobarEyzaguirre, P. Failler, A. M. M. Fouda, B. Fu, H. Gundimeda, S.
Hashimoto, F. Homer, S. Lavorel, G. Lichtenstein, W. A. Mala, W. Mandivenyi, P. Matczak, C. Mbizvo, M. Mehrdadi, J. P. Metzger, J. B. Mikissa, H. Moller, H. A. Mooney, P. Mumby, H. Nagendra, C. Nesshover, A. A. Oteng-Yeboah, G. Pataki, M. Roué, J. Rubis, M. Schultz, P. Smith, R. Sumaila, K. Takeuchi, S. Thomas, M. Verma, Y. Yeo-Chang, and D. Zlatanova. 2015. The IPBES Conceptual Framework - connecting nature and people. Current Opinion in Environmental Sustainability 14:1-16. http:// dx.doi.org/10.1016/j.cosust.2014.11.002

Dlamini, P., P. Chivenge, and V. Chaplot. 2016. Overgrazing decreases soil organic carbon stocks the most under dry climates and low soil pH: a meta-analysis shows. Agriculture, Ecosystems \& Environment 221:258-269. http://dx.doi.org/10.1016/j.agee.2016.01.026

Dlamini, P., P. Chivenge, A. Manson, and V. Chaplot. 2014. Land degradation impact on soil organic carbon and nitrogen stocks of sub-tropical humid grasslands in South Africa. Geoderma 235-236:372-381. http://dx.doi.org/10.1016/j.geoderma.2014.07.016

Dlamini, P., C. Orchard, G. Jewitt, S. Lorentz, L. Titshall, and V. Chaplot. 2011. Controlling factors of sheet erosion under degraded grasslands in the sloping lands of KwaZulu-Natal, South Africa. Agricultural Water Management 98:1711-1718. http://dx.doi.org/10.1016/j.agwat.2010.07.016

Duraiappah, A. K., S. T. Asah, E. S. Brondizio, N. Kosoy, P. J. O'Farrell, A.-H. Prieur-Richard, S. M. Subramanian, and K. Takeuchi. 2014. Managing the mismatches to provide ecosystem services for human well-being: a conceptual framework for understanding the New Commons. Current Opinions in Environmental Sustainability 7:94-100. http://dx.doi.org/10.1016/ j.cosust.2013.11.031

Egoh, B., E. G. Drakou, M. B. Dunbar, J. Maes, and L. Willemen. 2012. Indicators for mapping ecosystem services: a review. Report EUR 25456 EN. Publications Office of the European Union, Luxembourg.

Enfors, E. I., and L. J. Gordon. 2008. Dealing with drought: the challenge of using water system technologies to break dryland poverty traps. Global Environmental Change 18:607-616. http:// dx.doi.org/10.1016/j.gloenvcha.2008.07.006

Ernstson, H. 2013. The social production of ecosystem services: a framework for studying environmental justice and ecological complexity in urbanized landscapes. Landscape and Urban Planning 109(1):7-17. http://dx.doi.org/10.1016/j.landurbplan.2012.10.005

Essiet, E. U. 1990. A comparison of soil degradation under smallholder farming and large-scale irrigation land use in Kano State, Northern Nigeria. Land Degradation \& Development 2:209-214. http://dx.doi.org/10.1002/1dr.3400020306

Fagerholm, N., N. Käyhkö, F. Ndumbaro, and M. Khamis. 2012. Community stakeholders' knowledge in landscape assessments mapping indicators for landscape services. Ecological Indicators 18:421-433. http://dx.doi.org/10.1016/j.ecolind.2011.12.004

Foley, J. A., R. DeFries, G. P. Asner, C. Barford, G. Bonan, S. R. Carpenter, F. S. Chapin, M. T. Coe, G. C. Daily, H. K. Gibbs, J. H. Helkowski, T. Holloway, E. A. Howard, C. J. Kucharik, C. Monfreda, J. A. Patz, I. C. Prentice, N. Ramankutty, and P. K. Snyder. 2005. Global consequences of land use. Science 309:570-574. http://dx.doi.org/10.1126/science.1111772 
Francis, E. 2006. Poverty: causes, responses and consequences in rural South Africa. Chronic Poverty Research Centre Working Paper No. 60. Chronic Poverty Research Centre, London, UK. http://dx.doi.org/10.2139/ssrn.1753637

Green, M., and D. Hulme. 2005. From correlates and characteristics to causes: thinking about poverty from a chronic poverty perspective. World Development 33(6):867-879. http://dx. doi.org/10.1016/j.worlddev.2004.09.013

Haas, G., F. Wetterich, and U. Köpke. 2001. Comparing intensive, extensified and organic grassland farming in southern Germany by process life cycle assessment. Agriculture, Ecosystems \& Environment 83:43-53. http://dx.doi.org/10.1016/S0167-8809(00) 00160-2

Haider, L. J., W. J. Boonstra, G. D. Peterson, and M. Schlüter. 2018. Traps and sustainable development in rural areas: a review. World Development 101:311-321. http://dx.doi.org/10.1016/j. worlddev.2017.05.038

Hamann, M., R. Biggs, and B. Reyers. 2015. Mapping socialecological systems: identifying "green-loop" and "red-loop" dynamics based on characteristic bundles of ecosystem service use. Global Environmental Change 34:218-226. http://dx.doi. org/10.1016/j.gloenvcha.2015.07.008

Hein, L., K. van Koppen, R. S. de Groot, and E. van Ierland. 2006. Spatial scales, stakeholders and the valuation of ecosystem services. Ecological Economics 57:209-228. http://dx.doi. org/10.1016/j.ecolecon.2005.04.005

Henle, K., D. Alard, J. Clitherow, P. Cobb, L. Firbank, T. Kull, D. McCracken, R. F. A. Moritz, J. Niemelä, M. Rebane, D. Wascher, A. Watt, and J. Young. 2008. Identifying and managing the conflicts between agriculture and biodiversity conservation in Europe-a review. Agriculture, Ecosystems \& Environment 124:60-71. http://dx.doi.org/10.1016/j.agee.2007.09.005

Hodbod, J., O. Barreteau, C. Allen, and D. Magda. 2016. Managing adaptively for multifunctionality in agricultural systems. Journal of Environmental Management 183:379-388. http://dx.doi.org/10.1016/j.jenvman.2016.05.064

Hoffman, M. T., and S. Todd. 2000. A national review of land degradation in South Africa: the influence of biophysical and socio-economic factors. Journal of Southern African Studies 26:743-758. http://dx.doi.org/10.1080/713683611

Hole, D. G., A. J. Perkins, J. D. Wilson, I. H. Alexander, P. V. Grice, and A. D. Evans. 2005. Does organic farming benefit biodiversity? Biological Conservation 122:113-130. http://dx.doi. org/10.1016/j.biocon.2004.07.018

Holt, A. R., A. Alix, A. Thompson, and L. Maltby. 2016. Food production, ecosystem services and biodiversity: we can't have it all everywhere. Science of the Total Environment 573:1422-1429. http://dx.doi.org/10.1016/j.scitotenv.2016.07.139

Huntsinger, L., and J. L. Oviedo. 2014. Ecosystem services are social-ecological services in a traditional pastoral system: the case of California's Mediterranean rangelands. Ecology and Society 19(1):8. http://dx.doi.org/10.5751/ES-06143-190108

Kleijn, D., F. Kohler, A. Báldi, P. Batáry, E. D. Concepción, Y. Clough, M. Díaz, D. Gabriel, A. Holzschuh, E. Knop, A. Kovács,
E. J. P. Marshall, T. Tscharntke, and J. Verhulst. 2009. On the relationship between farmland biodiversity and land-use intensity in Europe. Proceedings of the Royal Society B: Biological Sciences 276:903-909. http://dx.doi.org/10.1098/rspb.2008.1509

Kongo, V. M., and G. P. W. Jewitt. 2006. Preliminary investigation of catchment hydrology in response to agricultural water use innovations: a case study of the Potshini catchment - South Africa. Physics and Chemistry of the Earth, Parts $A / B / C$ 31:976-987. http://dx.doi.org/10.1016/j.pce.2006.08.014

Kosgei, J. R., and G. P. W. Jewitt. 2009. Food production and household income among smallholder rainfed farmers: do biophysical and policy interventions have a common role in arid and semi-arid lands? Rainwater harvesting systems and their influences on field scale soil hydraulic properties, water fluxes and crop production. Dissertation. University of KwaZulu-Natal, Pietermaritzburg, South Africa.

Kosgei, J. R., G. P. W. Jewitt, V. M. Kongo, and S. A. Lorentz. 2007. The influence of tillage on field scale water fluxes and maize yields in semi-arid environments: a case study of Potshini catchment, South Africa. Physics and Chemistry of the Earth, Parts A/B/C 32:1117-1126. http://dx.doi.org/10.1016/j.pce.2007.07.027

Kremen, C., and A. Miles. 2012. Ecosystem services in biologically diversified versus conventional farming systems: benefits, externalities, and trade-offs. Ecology and Society 17 (4):40. http://dx.doi.org/10.5751/ES-05035-170440

Lade. S. J., L. J. Haider, G. Engström, and M. Schlüter. 2017. Resilience offers escape from trapped thinking on poverty alleviation. Science Advances 3(5):e1603043. http://dx.doi. org/10.1126/sciadv. 1603043

Lang, D. J., A. Wiek, M. Bergmann, M. Stauffacher, P. Martens, P. Moll, M. Swilling, and C. J. Thomas. 2012. Transdisciplinary research in sustainability science: practice, principles, and challenges. Sustainability Science 7:25-43. http://dx.doi. org/10.1007/s11625-011-0149-X

Lee, J. S. H., S. Abood, J. Ghazoul, B. Barus, K. Obidzinski, and L. P. Koh. 2014. Environmental impacts of large-scale oil palm enterprises exceed that of smallholdings in Indonesia. Conservation Letters 7:25-33. http://dx.doi.org/10.1111/conl.12039

Lele, M., and U. Agarwal. 1990. Smallholder and large-scale agriculture in Africa: are there trade-offs between growth and equity? MADIA Discussion Paper 6. World Bank, Washington, D.C., USA.

Lele, S., O. Springate-Baginski, R. Lakerveld, D. Deb, and P. Dash. 2013. Ecosystem services: origins, contributions, pitfalls, and alternatives. Conservation \& Society 11:343-58. http://dx.doi. org/10.4103/0972-4923.125752

Lovell, S. T., and D. M. Johnston. 2009. Creating multifunctional landscapes: how can the field of ecology inform the design of the landscape? Frontiers in Ecology and the Environment 7:212-220. http://dx.doi.org/10.1890/070178

Lynch, S. D. 2004. Development of a raster database of annual, monthly and daily rainfall for Southern Africa. Water Research Commission (WRC) Report 1156/1/04. WRC, Pretoria, South Africa. 
Malinga, R., L. J. Gordon, R. Lindborg, and G. Jewitt. 2013. Using participatory scenario planning to identify ecosystem services in changing landscapes. Ecology and Society 18(4):10. http://dx.doi.org/10.5751/ES-05494-180410

Mansour, K., T. Everson, and O. Mutanga. 2013. Evaluation of potential indicators for payment of environmental services on the impact of rehabilitation of degraded rangeland sites. African Journal of Agricultural Research 8:1290-1299. http://dx.doi. org/10.5897/AJAR12.1550

Martínez-Harms, M. J., and P. Balvanera. 2012. Methods for mapping ecosystem service supply: a review. International Journal of Biodiversity Science, Ecosystem Services \& Management 8:17-25. http://dx.doi.org/10.1080/21513732.2012.663792

Mchunu, C., and V. Chaplot. 2012. Land degradation impact on soil carbon losses through water erosion and $\mathrm{CO}_{2}$ emissions. Geoderma 177-178:72-79. http://dx.doi.org/10.1016/j. geoderma.2012.01.038

Mchunu, C. N., S. Lorentz, G. Jewitt, A. Manson, and V. Chaplot. 2011. No-till impact on soil and soil organic carbon erosion under crop residue scarcity in Africa. Soil Science Society of America Journal 75:1503-1512. http://dx.doi.org/10.2136/sssaj2010.0359

Milcu, A. I., J. Hanspach, D. Abson, and J. Fischer 2013. Cultural ecosystem services: a literature review and prospects for future research. Ecology and Society 18(3):44. http://dx.doi.org/10.5751/ ES-05790-180344

Pascual, U., P. Balvanera, S. Díaz, G. Pataki, E. Roth, M. Stenseke, R. T. Watson, E. Başak Dessane, M. Islar, E. Kelemen, V. Maris, M. Quaas, S. M. Subramanian, H. Wittmer, A. Adlan, S. Ahn, Y. S. Al-Hafedh, E. Amankwah, S. T. Asah, P. Berry, A. Bilgin, S. J. Breslow, C. Bullock, D. Cáceres, H. Daly-Hassen, E. Figueroa, C. D. Golden, E. Gómez-Baggethun, D. GonzálezJiménez, J. Houdet, H. Keune, R. Kumar, K. Ma, P. H. May, A. Mead, P. O'Farrell, R. Pandit, W. Pengue, R. Pichis-Madruga, F. Popa, S. Preston, D. Pacheco-Balanza, H. Saarikoski, B. B. Strassburg, M. van den Belt, M. Verma, F. Wickson, and N. Yagi. 2017. Valuing nature's contributions to people: the IPBES approach. Current Opinion in Environmental Sustainability 26-27:7-16. http://dx.doi.org/10.1016/j.cosust.2016.12.006

Percival, V., and T. Homer-Dixon. 1998. Environmental scarcity and violent conflict: the case of South Africa. Journal of Peace Research 35:279-298. http://dx.doi.org/10.1177/0022343398035003002

Plieninger, T., S. Dijks, E. Oteros-Rozas, and C. Bieling. 2013. Assessing, mapping, and quantifying cultural ecosystem services at community level. Land Use Policy 33:118-129. http://dx.doi. org/10.1016/j.landusepol.2012.12.013

Podwojewski, P., J. L. Janeau, S. Grellier, C. Valentin, S. Lorentz, and V. Chaplot. 2011. Influence of grass soil cover on water runoff and soil detachment under rainfall simulation in a sub-humid South African degraded rangeland. Earth Surface Processes and Landforms 36:911-922. http://dx.doi.org/10.1002/esp.2121

Pollard, S., H. Biggs, and D. R. Du Toit. 2014. A systemic framework for context-based decision making in natural resource management: reflections on an integrative assessment of water and livelihood security outcomes following policy reform in South Africa. Ecology and Society 19(2):63. http://dx.doi.org/10.5751/ ES-06312-190263
Reyers, B., R. Biggs, G. S. Cumming, T. Elmqvist, A. P. Hejnowicz, and S. Polasky. 2013. Getting the measure of ecosystem services: a social-ecological approach. Frontiers in Ecology and the Environment 11:268-273. http://dx.doi.org/10.1890/120144

Reyers, B., P. J. O'Farrell, J. L. Nel, and K. Wilson. 2012. Expanding the conservation toolbox: conservation planning of multifunctional landscapes. Landscape Ecology 27:1121-1134. http://dx.doi.org/10.1007/s10980-012-9761-0

Rockström, J., J. Williams, G. Daily, A. Noble, N. Matthews, L. Gordon, H. Wetterstrand, F. DeClerck, M. Shah, P. Steduto, C. de Fraiture, N. Hatibu, O. Unver, J. Bird, L. Sibanda, and J. Smith. 2017. Sustainable intensification of agriculture for human prosperity and global sustainability. Ambio 46:4-17. http://dx.doi. org/10.1007/s13280-016-0793-6

Ryan, R. L. 2011. The social landscape of planning: integrating social and perceptual research with spatial planning information. Landscape and Urban Planning 100:361-363. http://dx.doi. org/10.1016/j.landurbplan.2011.01.015

Sal, A. G., and A. G. García. 2007. A comprehensive assessment of multifunctional agricultural land-use systems in Spain using a multi-dimensional evaluative model. Agriculture, Ecosystems \& Environment 120:82-91. http://dx.doi.org/10.1016/j.agee.2006.06.020

Salomon, M. L. 2011. Keeping cattle in a changing rural landscape. Communal rangeland management in Okhombe, KwaZulu-Natal, South Africa. Dissertation. University of KwaZulu-Natal, Pietermaritzburg, South Africa.

Salomon, M., C. Cupido, and I. Samuels. 2013. The good shepherd: remedying the fencing syndrome. African Journal of Range \& Forage Science 30:71-75. https://doi.org/10.2989/10220119.2013.781064

Sinare, H., L. J. Gordon, and E. Enfors Kautsky. 2016. Assessment of ecosystem services and benefits in village landscapes - a case study from Burkina Faso. Ecosystem Services 21A:141-152. http://dx.doi.org/10.1016/j.ecoser.2016.08.004

Smith, M. T., J. S. Goebel, and J. N. Blignaut. 2014. The financial and economic feasibility of rural household biodigesters for poor communities in South Africa. Waste Management 34:352-362. http://dx.doi.org/10.1016/j.wasman.2013.10.042

Sonneveld, M. P. W., T. M. Everson, and A. Veldkamp. 2005. Multi-scale analysis of soil erosion dynamics in Kwazulu-Natal, South Africa. Land Degradation \& Development 16:287-301. http://dx.doi.org/10.1002/ldr.653

Stryamets, N., M. Elbakidze, M. Ceuterick, P. Angelstam, and R. Axelsson. 2015. From economic survival to recreation: contemporary uses of wild food and medicine in rural Sweden, Ukraine and NW Russia. Journal of Ethnobiology and Ethnomedicine 11:53. http://dx.doi.org/10.1186/s13002-015-0036-0

Sturdy, J. D., G. P. W. Jewitt, and S. A. Lorentz. 2008. Building an understanding of water use innovation adoption processes through farmer-driven experimentation. Physics and Chemistry of the Earth, Parts A/B/C 33:859-872. http://dx.doi.org/10.1016/ j.pce.2008.06.022

Taylor, G. R. 2010. Integrating quantitative and qualitative methods in research. University Press of America, Lanham, Maryland, USA. 
Thornton, A. 2009. Pastures of plenty?: Land rights and community-based agriculture in Peddie, a former homeland town in South Africa. Applied Geography 29:12-20. http://dx.doi. org/10.1016/j.apgeog.2008.06.001

van Berkel, D. B., and P. H. Verburg. 2014. Spatial quantification and valuation of cultural ecosystem services in an agricultural landscape. Ecological Indicators 37A:163-174. http://dx.doi. org/10.1016/j.ecolind.2012.06.025

Villamagna, A. M., P. L. Angermeier, and E. M. Bennett. 2013. Capacity, pressure, demand, and flow: a conceptual framework for analyzing ecosystem service provision and delivery. Ecological Complexity 15:114-121. http://dx.doi.org/10.1016/j.ecocom.2013.07.004

Wesely, J., 2010. Policy outcomes on water-related ecosystem services in an agricultural landscape in South Africa. Thesis. Stockholm University, Stockholm, Sweden.

Wilk, J., L. Andersson, and M. Warburton. 2013. Adaptation to climate change and other stressors among commercial and smallscale South African farmers. Regional Environmental Change 13:273-286. http://dx.doi.org/10.1007/s10113-012-0323-4

Wolff, S., C. J. E. Schulp, and P. H. Verburg. 2015. Mapping ecosystem services demand: a review of current research and future perspectives. Ecological Indicators 55:159-171. http://dx. doi.org/10.1016/j.ecolind.2015.03.016 
Appendix 1. Detailed methodology descriptions

Table A1.1. Detailed summary of ecosystem services, description of variables and data handling, category values and max values

\begin{tabular}{|c|c|c|c|c|c|c|c|c|}
\hline \multirow[b]{2}{*}{$\begin{array}{l}\text { Ecosystem } \\
\text { service }\end{array}$} & \multirow[b]{2}{*}{ Description and data handling } & \multirow[b]{2}{*}{ Variable type } & \multicolumn{5}{|c|}{ Category value } & \multirow[b]{2}{*}{ Max value } \\
\hline & & & 1 & 2 & 3 & 4 & 5 & \\
\hline $\begin{array}{l}\text { Crop } \\
\text { production }\end{array}$ & $\begin{array}{l}\text { The value representing crop production is the farmers' estimated annual crop } \\
\text { yield for maize and beans. The largescale commercial farmers (CF) produce } \\
\text { mostly } 50 \% \text { maize and } 50 \% \text { soya beans under a rotation scheme. The smallscale } \\
\text { farmers (SF) produced mainly maize and dry or sugar beans and the proportions } \\
\text { varied, both using crop rotation and intercropping. CF expressed their yield in } \\
\text { tons/hectare. In the cases when SF expressed their yield as bags/field or other, } \\
\text { we standardized the estimation to tons/hectares validating the data using } \\
\text { information from previous yield studies in the field area (Kosgei et al. 2007). }\end{array}$ & Categorical & $\begin{array}{l}0-20 \% \\
\text { of max }\end{array}$ & $\begin{array}{l}21-40 \% \\
\text { of max }\end{array}$ & $\begin{array}{l}41-60 \% \\
\text { of max }\end{array}$ & $\begin{array}{l}61-80 \% \\
\text { of max }\end{array}$ & $\begin{array}{l}81-100 \% \\
\text { of max }\end{array}$ & $\begin{array}{l}\text { The maximum yield of maize and } \\
\text { beans mentioned by any of the } \\
\text { farmers. }\end{array}$ \\
\hline $\begin{array}{l}\text { Crop } \\
\text { variety }\end{array}$ & $\begin{array}{l}\text { Crop variety is expressed as the number of different crops produced on the crop } \\
\text { fields and in the vegetable gardens. }\end{array}$ & Categorical & $\begin{array}{l}0-20 \% \\
\text { of max }\end{array}$ & $\begin{array}{l}21-40 \% \\
\text { of max }\end{array}$ & $\begin{array}{l}41-60 \% \\
\text { of max }\end{array}$ & $\begin{array}{l}61-80 \% \\
\text { of max }\end{array}$ & $\begin{array}{l}81-100 \% \\
\text { of max }\end{array}$ & $\begin{array}{l}\text { The maximum number of different } \\
\text { crops mentioned by any of the } \\
\text { farmers. }\end{array}$ \\
\hline $\begin{array}{l}\text { Livestock } \\
\text { production }\end{array}$ & $\begin{array}{l}\text { Livestock production is expressed as the number of cattle owned by the farmers. } \\
\text { Although some farmers have other animals than cattle, the most important } \\
\text { livestock in this area is cattle. The animal unit is not considered, and grazing } \\
\text { pressure and grazing methods are not part of the analysis. The CF livestock } \\
\text { numbers vary greatly over the seasons. Cattle are either bred, bought or leased } \\
\text { for grazing and/or breading in feed lots, for selling either as live animals or for } \\
\text { meat. The SF hold cattle not primarily for food production, but as an asset and } \\
\text { may be used for cultural purposes. Cattles are sold or slaughtered when there is a } \\
\text { specific cultural or economic need. To simplify the comparison of livestock } \\
\text { production between the CF and the SF, the cattle number is used as a measure of } \\
\text { food production and/or an asset. For both farmer groups, cattle graze in the } \\
\text { grazing lands during summer ( } 8 \text { months) and on the crop fields after harvest } \\
\text { during winter ( } 4 \text { months). The livestock value is hence divided between the land } \\
\text { uses grazing land and crop land according to the part of the year grazing occur. }\end{array}$ & Categorical & $\begin{array}{l}0-20 \% \\
\text { of max }\end{array}$ & $\begin{array}{l}21-40 \% \\
\text { of max }\end{array}$ & $\begin{array}{l}41-60 \% \\
\text { of max }\end{array}$ & $\begin{array}{l}61-80 \% \\
\text { of max }\end{array}$ & $\begin{array}{l}81-100 \% \\
\text { of } \max \end{array}$ & $\begin{array}{l}\text { The maximum number of cattle } \\
\text { owned by any of the farmers at the } \\
\text { point of the interview. }\end{array}$ \\
\hline Wild foods & $\begin{array}{l}\text { The value representing wild foods (wild herbs, fruits, berries, mushrooms and } \\
\text { animals) is expressed as the proportion of their family's food intake that is being } \\
\text { collected. }\end{array}$ & Categorical & $\begin{array}{l}\text { Very } \\
\text { little }\end{array}$ & Little & Half & Much & $\begin{array}{l}\text { Very } \\
\text { much }\end{array}$ & All \\
\hline $\begin{array}{l}\text { Building } \\
\text { materials }\end{array}$ & $\begin{array}{l}\text { The value representing building materials (sand, stones, clay, grass, logs, poles } \\
\text { and sticks) is expressed as the proportion of the family's use of building material } \\
\text { that is being collected. }\end{array}$ & Categorical & $\begin{array}{l}\text { Very } \\
\text { little }\end{array}$ & Little & Half & Much & $\begin{array}{l}\text { Very } \\
\text { much }\end{array}$ & All \\
\hline Fire wood & $\begin{array}{l}\text { The value representing fire wood (wood, twigs and cow dung) is expressed as } \\
\text { the proportion of their family's energy source for cooking is that is being } \\
\text { collected as fire wood. }\end{array}$ & Categorical & $\begin{array}{l}\text { Very } \\
\text { little }\end{array}$ & Little & Half & Much & $\begin{array}{l}\text { Very } \\
\text { much }\end{array}$ & All \\
\hline
\end{tabular}


Appendix 1. Detailed methodology descriptions

\begin{tabular}{|c|c|c|c|c|c|c|c|c|}
\hline \multirow{2}{*}{$\begin{array}{l}\text { Table A1.1 } \\
\text { Ecosystem } \\
\text { service }\end{array}$} & \multirow{2}{*}{$\begin{array}{l}\text { continued } \\
\text { Description and data handling }\end{array}$} & \multirow[b]{2}{*}{ Variable type } & \multicolumn{5}{|c|}{ "Category value } & \multirow[b]{2}{*}{ Max value } \\
\hline & & & 1 & 2 & 3 & 4 & 5 & \\
\hline Recreation & $\begin{array}{l}\text { The value representing recreation is expressed as the number of different } \\
\text { recreational activities carried out by the farmer's family in their land. }\end{array}$ & Categorical & $\begin{array}{l}0-20 \% \\
\text { of max }\end{array}$ & $\begin{array}{l}21-40 \% \\
\text { of max }\end{array}$ & $\begin{array}{l}41-60 \% \\
\text { of max }\end{array}$ & $\begin{array}{l}61-80 \% \\
\text { of max }\end{array}$ & $\begin{array}{l}81-100 \% \\
\text { of } \max \end{array}$ & $\begin{array}{l}\text { The maximum number of recreation } \\
\text { activities mentioned by any farmer. }\end{array}$ \\
\hline $\begin{array}{l}\text { Traditional } \\
\text { medicines }\end{array}$ & $\begin{array}{l}\text { The value representing traditional medicine (generally a variety of plant } \\
\text { material) is expressed as the proportion of the farmers within the farmer group } \\
\text { who collect traditional medicine. }\end{array}$ & Binary & & & & & & \\
\hline $\begin{array}{l}\text { Aesthetic } \\
\text { value }\end{array}$ & $\begin{array}{l}\text { The value representing aesthetic appreciation is expressed as the proportion of } \\
\text { the farmers within the farmer group who use specific places in their land for } \\
\text { aesthetic appreciation. }\end{array}$ & Binary & & & & & & \\
\hline $\begin{array}{l}\text { Social } \\
\text { relations }\end{array}$ & $\begin{array}{l}\text { The value representing social relations (the use of meeting places) is expressed } \\
\text { as the proportion of the farmers within the farmer group who use specific places } \\
\text { in their land for social relations. }\end{array}$ & Binary & & & & & & \\
\hline $\begin{array}{l}\text { Spiritual } \\
\text { value }\end{array}$ & $\begin{array}{l}\text { The value representing spiritual/religious meaning (the use of places for praying, } \\
\text { worshipping, spiritual fulfilment, connections with ancestors) is expressed as the } \\
\text { proportion of the farmers within the farmer group who use specific places in } \\
\text { their land for spiritual/religious meaning. }\end{array}$ & Binary & & & & & & \\
\hline $\begin{array}{l}\text { Water } \\
\text { availability }\end{array}$ & $\begin{array}{l}\text { The availability of water for crops, household use and the environment. Expert } \\
\text { assessment based on criteria and parameters found in Table A2. }\end{array}$ & Categorical & very low & low & medium & high & very high & \\
\hline $\begin{array}{l}\text { Water } \\
\text { flow } \\
\text { regulation }\end{array}$ & $\begin{array}{l}\text { The regulation of water flow, i.e. reducing high flows and floods, sustaining } \\
\text { slow flow of water supply. Expert assessment based on criteria and parameters } \\
\text { found in Table A2. }\end{array}$ & Categorical & very low & low & medium & high & very high & \\
\hline $\begin{array}{l}\text { Soil } \\
\text { erosion } \\
\text { regulation }\end{array}$ & $\begin{array}{l}\text { The regulation of soil erosion, i.e. reducing loss of soil and nutrients. Expert } \\
\text { assessment based on criteria and parameters found in Table A2. }\end{array}$ & Categorical & very low & low & medium & high & very high & \\
\hline $\begin{array}{l}\text { Nutrients } \\
\text { retention }\end{array}$ & $\begin{array}{l}\text { The retention of soil nutrients for availability to crops and vegetation. Expert } \\
\text { assessment based on criteria and parameters found in Table A2. }\end{array}$ & Categorical & very low & low & medium & high & very high & \\
\hline
\end{tabular}


Appendix 1. Detailed methodology descriptions

Table A1.2. Detailed description of category values, variables and criteria per land use for the expert assessment of the services water availability, water flow regulation, soil erosion regulation, and nutrient retention.

\begin{tabular}{|c|c|c|c|c|c|c|c|}
\hline \multirow[b]{2}{*}{ Service } & \multirow[b]{2}{*}{ Definition } & \multirow[b]{2}{*}{ Land use } & \multicolumn{5}{|c|}{ Category value, variables and criteria } \\
\hline & & & very low (1) & low (2) & medium (3) & high (4) & very high (5) \\
\hline \multirow[t]{2}{*}{$\begin{array}{l}\text { Water } \\
\text { availability }\end{array}$} & \multirow[t]{2}{*}{$\begin{array}{l}\text { The availability of } \\
\text { water for crops, } \\
\text { household use and the } \\
\text { environment. }\end{array}$} & crop & $\begin{array}{l}\text { Farmers with only rainfed } \\
\text { crop production, and very } \\
\text { low access to household } \\
\text { water e.g. no or little } \\
\text { small-scale rainwater } \\
\text { harvesting. Conventional } \\
\text { tillage, no cover crops and } \\
\text { very little mulching. }\end{array}$ & $\begin{array}{l}\text { Farmers with only rainfed } \\
\text { crop production, and low } \\
\text { access to household water } \\
\text { i.e. small-scale rainwater } \\
\text { harvesting for vegetable } \\
\text { gardens. No-till practices } \\
\text { but with limited mulching } \\
\text { and no or little cover crops, } \\
\text { increases soil moisture } \\
\text { slightly. }\end{array}$ & $\begin{array}{l}\text { Farmers with only } \\
\text { rainfed crop production, } \\
\text { but with full access to } \\
\text { household water. No-till } \\
\text { practices, cover crop } \\
\text { and mulching which } \\
\text { increase soil moisture. }\end{array}$ & $\begin{array}{l}\text { Farmers with a large } \\
\text { proportions of the land } \\
\text { irrigated and access to } \\
\text { large dams. No-till } \\
\text { practices, cover crop and } \\
\text { mulching which increase } \\
\text { soil moisture. }\end{array}$ & $\begin{array}{l}\text { Farmers with all land irrigated and } \\
\text { access to large dams. No-till } \\
\text { practices, cover crop and mulching } \\
\text { which increase soil moisture. }\end{array}$ \\
\hline & & grazing & $\begin{array}{l}\text { Very low vegetation } \\
\text { cover and very high } \\
\text { erosion rates. Rainfall } \\
\text { rates and frequencies. }\end{array}$ & $\begin{array}{l}\text { Low vegetation cover and } \\
\text { high erosion rates. Rainfall } \\
\text { rates and frequencies. }\end{array}$ & $\begin{array}{l}\text { Lands with medium } \\
\text { rainfall, lower lands. } \\
\text { Medium vegetation } \\
\text { cover and medium } \\
\text { erosion rates. Rainfall } \\
\text { rates and frequencies. }\end{array}$ & $\begin{array}{l}\text { Lands with higher } \\
\text { rainfall, higher up in the } \\
\text { mountains. High } \\
\text { vegetation cover and low } \\
\text { erosion rates. Rainfall } \\
\text { rates and frequencies. }\end{array}$ & $\begin{array}{l}\text { Lands with higher rainfall, higher } \\
\text { up in the mountains. Very high } \\
\text { vegetation cover and very low } \\
\text { erosion rates. Rainfall rates and } \\
\text { frequencies. }\end{array}$ \\
\hline $\begin{array}{l}\text { Water flow } \\
\text { regulation }\end{array}$ & $\begin{array}{l}\text { The regulation of } \\
\text { water flow, i.e. } \\
\text { reducing high flows } \\
\text { and floods, sustaining } \\
\text { slow flow of water } \\
\text { supply. }\end{array}$ & grazing & $\begin{array}{l}\text { Lands with very low } \\
\text { vegetation cover and very } \\
\text { high erosion rates. }\end{array}$ & $\begin{array}{l}\text { Lands with low vegetation } \\
\text { cover and high erosion } \\
\text { rates. }\end{array}$ & $\begin{array}{l}\text { Lands with medium } \\
\text { vegetation cover and } \\
\text { medium erosion rates. }\end{array}$ & $\begin{array}{l}\text { Lands with high } \\
\text { vegetation cover and low } \\
\text { erosion rates. }\end{array}$ & $\begin{array}{l}\text { Lands with very high vegetation } \\
\text { cover and very high erosion rates. }\end{array}$ \\
\hline
\end{tabular}


Appendix 1. Detailed methodology descriptions

\begin{tabular}{|c|c|c|c|c|c|c|c|}
\hline \multirow{2}{*}{$\begin{array}{l}\text { Table A1.2 } \\
\text { Service }\end{array}$} & \multirow{2}{*}{$\begin{array}{l}\text { continued } \\
\text { Definition }\end{array}$} & \multirow[b]{2}{*}{ Land use } & \multicolumn{5}{|c|}{ Category value, variables and criteria } \\
\hline & & & very low (1) & low (2) & medium (3) & high (4) & very high (5) \\
\hline \multirow[t]{2}{*}{$\begin{array}{l}\text { Soil erosion } \\
\text { regulation }\end{array}$} & \multirow[t]{2}{*}{$\begin{array}{l}\text { The regulation of soil } \\
\text { erosion, i.e. reducing } \\
\text { loss of soil and } \\
\text { nutrients. }\end{array}$} & crop & $\begin{array}{l}\text { Very eroded and degraded } \\
\text { lands. Very high soil loss } \\
\text { rates. Sloping land. } \\
\text { Farmers with } \\
\text { conventional tilling, no } \\
\text { cover crops and no or } \\
\text { little mulching. Heavily } \\
\text { grazed after harvest. }\end{array}$ & $\begin{array}{l}\text { Eroded and degraded lands. } \\
\text { High soil loss rates. Flat } \\
\text { land. Farmers with no-till } \\
\text { practices, no cover crops } \\
\text { and limited mulching. } \\
\text { Heavily grazed after } \\
\text { harvest. }\end{array}$ & $\begin{array}{l}\text { Lands with medium } \\
\text { erosion regulation. } \\
\text { Medium soil loss rates. } \\
\text { Farmers with no-till } \\
\text { practices, no cover } \\
\text { crops and limited } \\
\text { mulching. Grazing after } \\
\text { harvest. Presence of } \\
\text { contours which are } \\
\text { prone to erosion. }\end{array}$ & $\begin{array}{l}\text { Lands with high erosion } \\
\text { regulation. Low soil loss } \\
\text { rates. Farmers with no-till } \\
\text { practices, mostly cover } \\
\text { crops and mulching. } \\
\text { Grazing after harvest. } \\
\text { Presence of contours } \\
\text { which are prone to } \\
\text { erosion. }\end{array}$ & $\begin{array}{l}\text { Lands with very high erosion } \\
\text { regulation. Very low soil loss rates. } \\
\text { Farmers with no-till practices, cover } \\
\text { crops and mulching. Limited } \\
\text { grazing after harvest. Managing } \\
\text { contours which are prone to } \\
\text { erosion. }\end{array}$ \\
\hline & & grazing & $\begin{array}{l}\text { Very eroded and degraded } \\
\text { lands. Very high soil loss } \\
\text { rates. Farmers who are } \\
\text { not managing grazing } \\
\text { through rotation or } \\
\text { fencing off dongas, cattle } \\
\text { paths and eroded areas. }\end{array}$ & $\begin{array}{l}\text { Eroded and degraded lands. } \\
\text { High soil loss rates. } \\
\text { Farmers who have limited } \\
\text { managing grazing through } \\
\text { rotation or fencing off } \\
\text { dongas, cattle paths and } \\
\text { eroded areas. Some } \\
\text { rehabilitation areas present. }\end{array}$ & $\begin{array}{l}\text { Lands with medium } \\
\text { erosion levels. Medium } \\
\text { soil loss rates. Farmers } \\
\text { with grazing } \\
\text { management through } \\
\text { rotation and fencing off } \\
\text { dongas and with limited } \\
\text { grazing on eroded } \\
\text { lands. }\end{array}$ & $\begin{array}{l}\text { Lands with low erosion } \\
\text { levels. Low soil loss rates. } \\
\text { Farmers with grazing } \\
\text { management through } \\
\text { rotation and fencing off } \\
\text { dongas and no grazing on } \\
\text { eroded lands. }\end{array}$ & $\begin{array}{l}\text { Lands with very low erosion levels. } \\
\text { Very low soil loss rates. Farmers } \\
\text { with grazing management through } \\
\text { rotation and fencing off dongas and } \\
\text { no grazing on eroded lands and } \\
\text { active rehabilitation of eroded } \\
\text { lands. }\end{array}$ \\
\hline \multirow[t]{2}{*}{$\begin{array}{l}\text { Nutrient } \\
\text { retention }\end{array}$} & \multirow[t]{2}{*}{$\begin{array}{l}\text { The retention of soil } \\
\text { nutrients for } \\
\text { availability to crops } \\
\text { and vegetation. }\end{array}$} & crop & $\begin{array}{l}\text { Lands with very low } \\
\text { nutrient levels and very } \\
\text { low organic carbon levels. } \\
\text { Farmers with } \\
\text { conventional tillage, no } \\
\text { cover crops, no or little } \\
\text { mulching. High levels of } \\
\text { soil loss. }\end{array}$ & $\begin{array}{l}\text { Lands with low nutrient } \\
\text { levels and low organic } \\
\text { carbon levels. Farmers who } \\
\text { practice no-till, but no cover } \\
\text { crops and limited mulching. }\end{array}$ & $\begin{array}{l}\text { Lands with medium } \\
\text { nutrients levels and } \\
\text { medium organic carbon } \\
\text { levels. Farmers who } \\
\text { practice no-till but still } \\
\text { need external input. }\end{array}$ & $\begin{array}{l}\text { Lands with high nutrients } \\
\text { levels and high organic } \\
\text { carbon levels. Farmers } \\
\text { who have practiced no-till } \\
\text { for many years but need } \\
\text { external input. }\end{array}$ & $\begin{array}{l}\text { Lands with very high nutrient levels } \\
\text { and very high organic carbon } \\
\text { levels. }\end{array}$ \\
\hline & & grazing & $\begin{array}{l}\text { Lands with very low } \\
\text { nutrient levels and very } \\
\text { low organic carbon levels. } \\
\text { Very low vegetation } \\
\text { cover. }\end{array}$ & $\begin{array}{l}\text { Lands with low nutrient } \\
\text { levels and low organic } \\
\text { carbon levels. Low } \\
\text { vegetation cover. }\end{array}$ & $\begin{array}{l}\text { Lands with medium } \\
\text { nutrient levels and } \\
\text { medium organic carbon } \\
\text { levels. Medium } \\
\text { vegetation cover. }\end{array}$ & $\begin{array}{l}\text { Lands with high nutrient } \\
\text { levels and high organic } \\
\text { carbon levels. High } \\
\text { vegetation cover. }\end{array}$ & $\begin{array}{l}\text { Lands with very high nutrient levels } \\
\text { and very high organic carbon } \\
\text { levels. Very high vegetation cover. }\end{array}$ \\
\hline
\end{tabular}


Appendix 1. Detailed methodology descriptions

Table A1.3. Detailed description of factors used as criteria for the estimation of the farmers groups' capacity to maintain the supply and meet the demand of services: a) smallholder, b) commercial.

\begin{tabular}{|c|c|c|c|c|}
\hline \multirow{2}{*}{$\begin{array}{l}\text { a) } \\
\text { Ecosystem services }\end{array}$} & \multicolumn{3}{|c|}{ Smallholder } & \multirow[b]{2}{*}{ Factors that influence capacity to maintain the supply and meet the demand } \\
\hline & Supply & Demand & Capacity & \\
\hline Crop production & Low & High & Low & Water and soil conditions are poor, high levels of poverty, limited capacity to implement innovations \\
\hline Crop variety & High & High & Medium & Water and soil conditions are poor, high levels of poverty, diversifying of crops is relatively easy \\
\hline Livestock production & Low & High & Low & Water and soil conditions are poor, high levels of poverty, communal grasslands, limited influence by individual farmers \\
\hline Wild foods & Medium & High & Low & Water and soil conditions are poor, communal grasslands, limited influence by individuals, pressure on common-resources \\
\hline Building material & Medium & High & Low & Water and soil conditions are poor, communal grasslands, limited influence by individuals, pressure on common-resources \\
\hline Fire wood & Medium & High & Low & Water and soil conditions are poor, communal grasslands, limited influence by individuals, pressure on common-resources \\
\hline Cultural heritage & Medium & Medium & Medium & Water and soil conditions are poor, limited influence by individual farmers, pressure on common-resources \\
\hline Recreation & Low & Low & High & Opportunities for recreation on communal lands are present. Accessibility high. \\
\hline Traditional medicine & High & High & Low & Communal lands, pressure on common-resources \\
\hline Aesthetic & High & High & Medium & Soil conditions are poor, limited influence by individual farmers to manage communal lands \\
\hline Spiritual/religious & High & High & High & No direct limiting factors to maintain spiritual/religious values \\
\hline Social relations & High & High & High & No direct limiting factors to maintain social relation \\
\hline Water availability & Low & High & Low & Soil conditions are poor, high levels of poverty, lack of infrastructure \\
\hline Water flow regulation & Low & High & Low & Soil conditions are poor, high levels of poverty, limited influence by individual farmers to manage communal lands \\
\hline Erosion regulation & Low & High & Low & Soil conditions are poor, high levels of poverty, limited capacity to implement innovations \\
\hline Nutrient retention & Low & High & Low & Soil conditions are poor, high levels of poverty, limited capacity to implement innovations \\
\hline (b) & \multicolumn{3}{|c|}{ Commercial } & \\
\hline Ecosystem services & Supply & Demand & Capacity & Factors that influence capacity to maintain the supply and meet the demand \\
\hline Crop production & High & High & High & Water and soil conditions ok, no poverty, infrastructure in place, private land ownership \\
\hline Crop variety & Medium & Medium & High & Water and soil conditions ok, no poverty, diversifying of crops is relatively easy, market driven \\
\hline Livestock production & Medium & Medium & Medium & Water and soil conditions are ok, no poverty, private grasslands, infrastructure and management practices in place \\
\hline Wild foods & Low & Low & High & Water and soil conditions are ok, private lands, little pressure on resources \\
\hline Building material & Low & Low & High & Water and soil conditions are ok, private lands, little pressure on resources \\
\hline Fire wood & Low & Low & High & Water and soil conditions are ok, private lands, little pressure on resources \\
\hline Cultural heritage & Low & Low & High & No direct limiting factors to maintain cultural heritage values \\
\hline Recreation & Medium & Medium & High & Accessibility high, no poverty, private lands \\
\hline Traditional medicine & Low & Low & High & No direct limiting factors to maintain traditional medicine \\
\hline Aesthetic appreciation & High & High & High & Soil conditions are ok, no poverty, private lands \\
\hline Spiritual/religious & Medium & Medium & High & No direct limiting factors to maintain spiritual/religious values \\
\hline Social relations & Low & Low & High & No direct limiting factors to maintain social relation \\
\hline Water availability & High & High & Medium & Soil conditions are ok, no poverty, infrastructure in place, still dependent on rainfall \\
\hline Water flow regulation & High & High & Medium & Soil conditions are ok, no poverty, still dependent on rainfall \\
\hline Erosion regulation & High & High & High & Soil conditions are ok, no poverty, private landownership, management practices in place \\
\hline Nutrient retention & High & High & High & Soil conditions are ok, no poverty, private landownership, management practices in place \\
\hline
\end{tabular}


Appendix 2. Questionnaire and guide for in-depth interviews and participatory mapping exercise.

\section{Information according to ethical consideration, given to the respondents prior to the interview.}

1. The respondent was informed about the project, the purpose and expected outcomes.

2. The respondent may ask any question prior to, during or after the interview, and be answered to their satisfaction.

3. The respondent has been given the contact details to the interviewer and may contact them with regards to any queries.

4. The respondent may withdraw from the participation any time.

5. The information gathered during the interview will be handled with strict confidentiality. Names, contact details or exact locations of the respondent's homes or land will not be revealed, shared or published.

6. The respondent's confidentiality is guaranteed as their input will not be attributed to them in person but reported as a population member opinion, or anonymously if direct citation.

\section{Background information about the correspondent}

1.1 Gender. $\square$ male $\square$ female 1.2 Age. $\square 20-30 \square 30-40 \square 40-50 \square 50-60 \square 60-70 \square 70-80 \square 80-90$ 1.3 Occupation. 1.4 Means of transport. How do you move around on Your land? (rank if more than one option) $\square$ walk $\square$ bicycle $\square$ horse $\square$ car $\square$ tractor $\square$ motorbike $\square$ kumbi taxi $\square$ other. How do you move around in the wider landscape? (rank if more than one) $\square$ walk $\square$ bicycle $\square$ horse $\square$ car $\square$ tractor $\square$ motorbike $\square$ kumbi taxi $\square$ other. 1.5 For whom do you produce food? Who buys/receives/eats the food you produce? (rank if more than one option) In a normal year: $\square$ Me and my family $\square$ my neighbors and nearby community $\square$ the wider society. In a dry year: $\square$ Me and my family $\square$ my neighbors and nearby community $\square$ the wider society. In a wet year: $\square$ Me and my family $\square$ My neighbors and nearby community $\square$ The wider society.

\section{Personal values attached to Your land and the landscape in which you move around}

2.1 Farmer identity. Origin: Born: Raised: Lived here since: $\mathbf{2 . 2}$ How many generations back have this farm belonged to your family? Describe. 2.3 Would you like your children/grand children to take over after you? 2.4 What does it mean to you to be a farmer? 2.5 Do you find pride and joy of production? Do you farm for money or for pride and joy of production? Would you carry on if profits decreased? Describe. 2.6 Do you feel you have a responsibility towards your family, your community and/or the society to produce food, and to keep your farm/ landscape neat and tidy, and to manage in a way to minimize the negative outcomes of farming? Describe.

2.7 Farm inheritance. How much of what you know have you learnt from the one who managed this farm before you? And further back? Where did you gain your farming knowledge? Describe. 2.8 Do you enjoy being a farmer? 2.9 Would you have chosen a different job or lifestyle if you were to go back in time?

2.10 Aesthetic values. Where in Your land do you appreciate exceptional beauty? Describe. 2.11 In the landscape in which you move around? Describe.

2.12 Recreation Where in Your land are sites for recreation, used by you, your family or others. Walking, running, cycling, canoeing, camping, dog walking, fishing, hunting, etc.? Describe. 2.13 In the landscape in which you move around? Describe.

2.14 Spiritual/Religious values. Where in Your land are sites of spiritual or religious value? Sites that are associated with connections with gods, spirits or ancestors? Sacred places, graves etc. Describe. 2.15 In the landscape in which you move around? Describe. 
Appendix 2. Questionnaire and guide for in-depth interviews and participatory mapping exercise.

2.16 Social relations. Where in Your land are sites serving as meeting points, either personal or institutional? Places for rituals and ceremonies? Describe. 2.17 In the landscape in which you move around? Describe.

Box 1. Cultural heritage. The legacy of biophysical features, physical artifacts, and intangible attributes of a group or society that are inherited from past generations, maintained in the present, and bestowed for the benefit of future generations. Cultural landscapes are significant constituents of cultural heritage. Examples: Certain type of forest, bush, grassland, cultivated lands (classical pastoral landscapes, wine, tea, coffee, and fruit plantations, terraced landscapes etc.), certain plants, trees, animal species, solitary trees, hedgerows, alleys, tree lines, drainage ditches, traditional buildings, places for ceremonies, places to collect/harvest flora/fauna and other natural resources for culturally significant purposes (traditional attire, decorations etc).

2.18 Cultural heritage value, see Box 1. Where in Your land are sites significant for your culture? Describe. 2.19 In the landscape in which you move around? Describe. 2.20 Where in Your land are sites significant for your local history? Describe. 2.21 In the landscape in which you move around? Describe.

\section{Agricultural activities}

3.1 Where is your house? (Mark at map) 3.2 Other buildings? (Mark at map)

3.3 Crops. Where are your fields? Indicate crop types. (Mark at map) 3.4 Which traditional /indigenous crops to you use? 3.5 Do you use seeds from your own harvest? 3.6 How do you water your crops? 3.7 Crop yields: Dry year, normal year, wet year

3.8 Vegetable gardens (mark at map). Do you have a vegetable garden? What vegetables do you grow? 3.9 Do you usually produce enough vegetables to sell?

3.10 Livestock. What livestock do you have, and how many of each? 3.11 Where do they graze or feed? (Mark at map) 3.12 Do you produce the feed for your livestock? 3.13 Where do the animals stay at night? 3.14 Do your livestock numbers vary in dry, normal or wet years?

\section{Natural land}

4.1 Mark all places/patches with natural land (land not paved, cultivated or used for grazing etc) Examples: tree lines, ditches, grass margins, stretches of forest or bush, forest corridors, grassland, wetland, rivers.

4.2 Non-cultivated provisioning services. Where in Your land do you collect wild foods (flora/fauna)? Describe. 4.3 In the landscape in which you move around? Describe. 4.4 How dependent are you of the collection of wild foods? Wild foods constitute $\square \%$ of what we eat, or: $\square$ very small part $\square$ small part $\square$ half $\square$ large part $\square$ very large part. 4.5 Does the dependence of wild foods change in dry years?

4.6 Where in Your land do you collect building materials? Describe. 4.7 In the landscape in which you move around? Describe. 4.8 How dependent are you of the collection of building materials? Natural building materials constitute $\square \%$ of what we build with, or: avery small part $\square$ small part $\square$ half $\square$ large part $\square$ very large part. 4.9 Does the dependence of natural building materials change in dry years? 
Appendix 2. Questionnaire and guide for in-depth interviews and participatory mapping exercise.

4.10 Where in Your land do you collect fire wood? Describe. 4.11 In the landscape in which you move around? Describe. 4.12 How dependent are you of the collection of fire wood? Collected fire wood constitutes $\square \%$ of what we use for cooking/heating etc., or: $\square$ very small part $\square$ small part $\square$ half $\square$ large part $\square$ very large part. 4.13 Does the dependence of collected fire wood change in dry years?

4.14 Where in Your land do you collect traditional medicines? Describe. 4.15 In the landscape in which you move around? Describe. 4.16 How dependent are you of the collection of traditional medicines? Traditional medicines (which your family collects) constitute $\square \%$ of what we use for remedies of illnesses, or: $\square$ very small part $\square$ small part $\square$ half $\square$ large part $\square$ very large part. 4.17 Does the dependence of traditional medicines (which your family collects) in dry years? 